\title{
Synthesis of thermal tolerances of the common freshwater fish species in large Western Europe rivers
}

\author{
Y. Souchon ${ }^{(1) \star}$, L. Tissot $^{(2)}$ \\ Received February 20, 2012 \\ Revised March 12, 2012 \\ Accepted March 12, 2012
}

\section{ABSTRACT}

Key-words:

fish, temperature, thermal tolerance, climate warming
The effects of industrial cooling water on fish communities were widely debated at the end of the seventies, when large thermal power plants were being developed. This led to numerous research programs on thermal tolerance in fish. The recent warming climatic period and especially the 2003 heat wave have brought thermal biology back to center stage. The work presented here has consisted in analyzing historical and contemporary literature to update basic knowledge on thermal tolerances of 19 riverine fish species. These data were then validated and completed by European fish specialists. We finally proposed a synthesis, based on more than 300 references, which details thermal tolerances for the entire life cycle: reproduction, embryonic, larval, juvenile and adult life stages. This updated material is of great importance to an understanding of the trends observed in fish communities or for forecasting future behavior in climate change scenarios.

RÉSUMÉ

Synthèse des tolérances thermiques des espèces de poissons communes des rivières et fleuves de plaine de l'ouest européen
Mots-clés :
L'effet de l'élévation de température des cours d'eau a été largement débattu à la poissons, température, tolérance thermique, fin des années 70 qui ont connu le développement des centrales thermiques de grande puissance. Ces études ont généré alors de nombreux programmes de recherche sur la tolérance thermique des poissons, dont les résultats sont parfois oubliés ou difficiles à rassembler. Le réchauffement climatique actuel et en parti- culier l'épisode caniculaire de 2003 a mis de nouveau ce thème sur le devant de la réchauffement climatique

(1) Irstea, UR MALY Milieux aquatiques, écologie et pollutions, Laboratoire d'Hydroécologie Quantitative, Pôle Études et recherche Onema/Irstea, Hydroécologie des cours d'eau, 3 bis quai Chauveau, CP 220, 69336 Lyon, France

(2) EDF Recherche and Développement, Laboratoire National d'Hydraulique et Environnement, 6 quai Watier, 78401 Chatou Cedex, France.

*Corresponding author: yves.souchon@irstea.fr 


\section{INTRODUCTION}

The effect of water temperature on aquatic organisms was a central theme of research in aquatic ecology in the Seventies, in response to concerns among the public of the impact of industrial installations dependent on cooling water in their processes, with this water then being restituted at higher temperature to rivers (Leynaud, 1967; Talmage, 1977). Subsequent to the installation of atmospheric cooling towers, this topic ceased to draw as much attention for close to three decades, but returned to center stage on a major scale following the European heat wave of 2003 (De Bono et al., 2004) and particularly in light of data on global warming (in the 20th century, a mean rise of air temperature each decade of $+0.10^{\circ} \mathrm{C}$ to $0.16{ }^{\circ} \mathrm{C}$, according to the Intergovernmental Panel on Climate Change, 2007) and in view of GIEC forecasts (predicted temperature in 2090-2099 in comparison with 1980-1999: $+1.8^{\circ} \mathrm{C}$ to $4.0^{\circ} \mathrm{C}$ depending on the scenario, GIEC, 2007). On a more local scale, more insidious disruptions in thermal regimes have also been noted in recent years: the effects of urbanization and heating of water by water treatment stations (Kinouchi, 2007: $+0.11{ }^{\circ} \mathrm{C}$ to $0.22{ }^{\circ} \mathrm{C}$ per year on sites affected by releases from large agglomerations like Tokyo) or by the increase of impermeabilized surfaces (Leblanc et al., 1997), the effects of dams which can result in a rise or a drop of the downstream temperature (Quinn and Adams, 1996 in Petersen and Kitchell, 2001; Olden and Naiman, 2010: threshold of $15.5^{\circ} \mathrm{C}$ reached 1 month earlier in spring and 15 days later in fall, Columbia River, Bonneville Dam, USA) or the effects of diminishing riparian cover on rivers, leaving larger surfaces of water open to direct solar radiation (Bartholow, 2000: $+3^{\circ} \mathrm{C}$ to $6{ }^{\circ} \mathrm{C}$ for the mean daily temperature and $+3^{\circ} \mathrm{C}$ to $8{ }^{\circ} \mathrm{C}$ for the maximum temperature averaged over a number of cases; Burton and Likens, 1973 in Kaushal et al., 2010 and Moore et al., 2005: daily maximum of $4{ }^{\circ} \mathrm{C}$ to $5{ }^{\circ} \mathrm{C}$ higher following a wooded riparian area clear cut).

In ecology, temperature is a key abiotic factor, more difficult to interpret than in physics given that one must take into consideration not only instantaneous values but also their annual, seasonal and daily variation. Cumulative temperatures in a range favorable for organisms impact their physiology (the sum of degree days or of daily means above $0{ }^{\circ} \mathrm{C}$ or above a known threshold for a target species, Allan, 1995). From a functional perspective, temperature acts on physico-chemical variables (e.g. the solubility of oxygen), on the speed of recycling of nutrients or of decomposition of organic matter, and on the metabolic dynamics of living organisms (e.g. primary production). Critical periods for aquatic organisms may, for example, occur in the case of simultaneity of a hydric stress like a low-water episode and a high temperature in the aquatic environment (Miller et al., 2007). On the scale of biota, particularly poikilothermic organisms, the temperature of the surrounding environment influences the metabolism (Gillooly et al., 2001; Brown et al., 2004), the rate of ingestion and digestion (Brett and Higgs, 1970; Tseitlin, 1980), and reproductive cycles (De Vlaming, 1972), with demands that vary during ontogenesis (Lapkin et al., 1983 in Raat, 1988). Swimming behavior (Mann and Bass, 1997; Ojanguren and Brana, 2000) and speed of growth (Wieser et al., 1988; Wolter, 2007) are also temperature-dependent. Consequently, the dynamics of populations and communities, their relative composition (Kishi et al., 2005) and their size distribution (Daufresne et al., 2009) are in large proportion governed by ambient thermal regimes. Depending on their requirements and their thermal tolerances, ectothermic species will or will not cope with new environmental conditions: some will decline, and even disappear from some geographical zones (Webb, 1996; ex. certain mollusks in the Saône River, France, Mouthon and Daufresne, 2006), while others, on the contrary, will expand their area of distribution (Hickling et al., 2006). To fully understand the changes observed or to anticipate the future state of species distribution, it is essential to know their thermal preferenda; interpretation of temperature should, however, be nuanced given that certain behaviors (Davey et al., 2006; aptitude to dispersion, ability to find thermal shelters, Torgersen et al., 1999) and certain phenotypic aptitudes (plasticity in the period of development, Schaefer and Ryan, 2006) enable some species to survive critical thermal episodes. 
Recent syntheses on the thermal requirements of temperate fish species have focused on temperatures in the embryonic and reproduction phases (Teletchea et al., 2007, 2009b), for species interesting from a zootechnical perspective. Partial syntheses were also published earlier (Hokanson, 1977; Alabaster and Lloyd, 1982; Mann, 1996; Küttel et al., 2002; Teletchea et al., 2009a), but to our knowledge, there has been no recent synthesis available to all stages of fish species commonly found in medium-size and large rivers.

This article meets that need for understanding the thermal profiles of nineteen species which constitute the core of the fish communities, not including salmonids, found in streams of river class 5 or larger in Western Europe (Keith et al., 2011; Teletchea, 2011).

When they were available, we give the requirements for all developmental stages (adult, embryo, larval, juvenile) or specific critical period (reproduction), based on observations in both natural and controlled. We follow common definitions of the literature for these life stages (Balon, 1975), e.g. "embryo" corresponds to the incubation period from fertilization up to the hatching of larvae. The literature available via digital documentary databases does not always include some interesting, though sometimes quite dated, texts, which may even be unscientific or poorly referenced texts in native languages (German, French). We made a significant effort to exploit all those we could access; we completed our work by directly questioning European authors ( 23 contacted) likely to have this type of information. For the 19 species studied (Table I), the compilation bears on more than 300 references. The complete bibliographical information is provided in Appendix.

\section{Table I}

Latin code, Family, English name, Latin name and French code of the 19 studied species.

\begin{tabular}{|l|c|c|c|c|}
\hline $\begin{array}{l}\text { Code } \\
\text { Latin }\end{array}$ & Family & English name & Latin name & $\begin{array}{c}\text { Code } \\
\text { French }\end{array}$ \\
\hline Alb & Cyprinidae & Bleak & Alburnus alburnus & ABL \\
\hline Bar & Cyprinidae & Barbel & Barbus barbus & BAF \\
\hline Tel & Cyprinidae & Vairone & Telestes souffia & BLN \\
\hline Rho & Cyprinidae & Bitterling & Rhodeus sericeus & BOU \\
\hline Bli & Cyprinidae & White bream & Blicca bjoerkna & BRB \\
\hline Abr & Cyprinidae & Common bream & Abramis brama & BRE \\
\hline Eso & Esocidae & Northern pike & Esox lucius & BRO \\
\hline Lec & Cyprinidae & Chub & Leuciscus cephalus & CHE \\
\hline Rut & Cyprinidae & Roach & Rutilus rutilus & GAR \\
\hline Gob & Cyprinidae & Gudgeon & Gobio gobio & GOU \\
\hline Gym & Percidae & Ruffe & Gymnocephalus cernuus & GRE \\
\hline Chn & Cyprinidae & French nase & Chondrostoma nasus & HOT \\
\hline Per & Percidae & Eurasian perch & Perca fluviatilis & PER \\
\hline Lep & Centrarchidae & Pumpkinseed & Lepomis gibbosus & PES \\
\hline San & Percidae & Pike perch & Sander lucioperca & SAN \\
\hline Sil & Siluridae & Catfish & Silurus glanis & SIL \\
\hline Abb & Cyprinidae & Spirlin & Alburnoides bipunctatus & SPI \\
\hline Cht & Cyprinidae & Sofie & Chondrostoma toxostoma & TOX \\
\hline Lel & Cyprinidae & Dace & Leuciscus leuciscus & VAN \\
\hline
\end{tabular}


Given the intrinsic disparity in sources and methods for calculating the important thermal variables (Beitinger and Bennett, 2000, list 450 tolerance values for 116 species), we begin by explaining the definitions retained. We then comment on the data for each species analyzed. Lastly, we propose a synthesis of the thermal ranges tolerated, grouping species with similar requirements.

\section{DEFINITIONS AND METHODOLOGY}

\section{> RANGE OF OPTIMUM TEMPERATURES}

Within their range of optimum temperatures, fish feed and show no signs of abnormal behavior; they are not in a state of stress (Elliott, 1981). Within this temperature range, physiological adjustments come effectively into play to enable the fish to withstand relatively high temperatures: induction of thermal stress proteins, modification of fatty acids in membranes (Iwama et al., 1998). The lower limit of this range is the minimum optimum temperature and the upper limit, the maximum optimum temperature.

\section{> EFFECT ON THE PERIOD OF DEVELOPMENT}

In fish, gametogenesis and egg-laying take place within well-defined temperature ranges. As for other physiological functions, there is a range of optimum temperatures for reproduction and upper and lower thermal thresholds above and below which gametogenesis and spawning are no longer possible.

The number of degree days is the unit by which we can determine the period of embryonic development as a function of the mean daily water temperature: for example, the period between two specific stages in development. The number of degree days is obtained by adding the mean temperature on each day between the two development stages in question. Most of the time, this number is measured in the laboratory at a given temperature which remains constant throughout the experiment, and is then calculated by multiplying this temperature by the period of embryonic development (in number of days).

\section{> EXPERIMENTALLY ESTABLISHED CRITICAL TEMPERATURE AND LETHAL TEMPERATURE}

\section{Definitions}

Thermal stress causes reactions which follow three successive phases in fish. These were identified in the laboratory and well described by Elliott (1981). The first phase is characterized by reluctance to feed, sudden sequences of activity during which the fish bump against the wall of the aquarium, momentary loss of balance, defecation and rapid respiratory movements. In the second phase, the fish becomes immobile but shows brusque though feeble swimming motions; most of the time it floats on its side or back; it may rapidly change color and ventilation movements speed up. The last phase is characterized by restricted movements which can only be seen around the operculum, the pectoral fins and the eyes; this continues until the fish is dead. If the fish are placed in cooler and better oxygenated water, those which have reached the last stress phase do not recover but die (experiments conducted by Cocking, 1959 on roach (Rutilus rutilus) and by Elliott, 1981 on trout (Salmo trutta).

\section{Range of resistance to temperature}

During episodes of thermal stress, physiological protection mechanisms are overwhelmed by the rapid appearance of the effects; fish can, however, "resist" for a certain time without suffering serious damage or at least with a high survival rate. This range of temperatures within which the fish suffer from thermal stress is called the "zone of resistance". 


\section{Range of tolerance to temperature}

Within the "zone of resistance", there is a "zone of tolerance" within which stress behavior does not occur and survival of the fish is, in theory, certain. In this zone, the fish survive the thermal shock but their physiological functions (feeding, respiration, growth) can be affected. Thermal tolerance therefore only has meaning in the short term (from one to a few days maximum). This zone is most often delimited by the lethal temperatures determined in the 24to 48-hour range. The data collected over longer periods (7 days) begin to integrate physiological effects other than merely thermal stress.

\section{Lethal temperature: instantaneous mortality}

In the zone of resistance, the temperature at which all fish die in less than ten minutes corresponds to the temperature of instantaneous mortality (Cocking, 1959).

\section{Experimental methods for determining these temperatures}

Two experimental methods were developed to characterize thermal stress, essentially in the 60s and 70s: the Critical Thermal Method - CTM, and the method based on the temperature causing the first mortalities, Incipient Lethal Temperature - ILT.

These two methods for determining thermal tolerance in fish species do not arrive at the same boundary temperatures because of the different experimental conditions, even though in both cases, they correlate positively with the acclimation temperature.

\section{Acclimation temperature}

The acclimation temperature is the temperature to which batches of fish are experimentally exposed for several days (at least a week, according to Fry, 1971) prior to a thermal tolerance test (Armour, 1991). The acclimation temperature is within the zone of tolerance of the fish.

\section{Determination of critical temperatures}

CTM is a technique for determining thermal tolerance of fish in the laboratory. It was initially fine-tuned in order to study amphibians, then extended to fish (Cowles and Bogert, 1944).

A sample of fish acclimated to a given temperature is subjected to a linear rise (or drop) in temperature up/down to a predefined sublethal threshold (which is nonetheless close to the lethal temperature). This threshold, which corresponds to the Critical Temperature (CT) maximum or CT minimum value, is the point at which movement of the fish becomes uncoordinated and they are no longer able to flee the conditions which may ultimately result in death (Houston, 1982). According to this methodology, the "lethal temperature" thermal variable is estimated without killing any individuals; the damage observed is reversible and there is no lethal effect. The choice of the sublethal criterion can vary with the author: Beitinger et al. (2000), for example, cite the onset of violent muscular spasms (Matthews and Maness, 1979), the loss of balance (Watenpaugh et al., 1985) or opening of the opercula (Middaugh et al., 1975).

The boundary temperatures obtained with this type of experiment are often higher than those found with the ILT method, due to the generally shorter period of exposure to the tested temperatures (Todd et al., 2008).

\section{Determination of lethal temperatures}

ILT is the oldest and most common laboratory method for investigating lethal temperature. It was developed by Fry et al. (1942) on the basis of studies of the relationship between thermal dose/response (Bliss, 1937). 
Batches of fish acclimated to a given temperature are suddenly transferred into water which is warmer or cooler than the temperature of acclimation and left for a variable period of time. The proportion of dead fish is then measured in each batch. The data are then statistically processed to determine the lethal temperature.

The lethal temperature $(\mathrm{LT} x, y)$ is the temperature which causes the death of a fraction of a batch of fish $(x)$ after a given period of exposure $(y)$. The periods in question generally vary from 100 min to $24 \mathrm{~h}$, and sometimes up to $96 \mathrm{~h}$. For example, 24-hour LT50 is the lethal temperature for $50 \%$ of the test batch after $24 \mathrm{~h}$. When the rate of mortality is not given, it is assumed to be LT50, which is the variable determined with the least uncertainty in experiments. By analogy, LC50 for dioxygen corresponds to the dioxygen concentration which is lethal for half of the individuals tested at a given acclimation temperature.

Practical tests in water warmer or cooler than the acclimation temperature provide respectively higher and lower lethal temperatures.

For a given biological stage (eggs, larvae, juveniles, adults), the lethal temperature depends on the acclimation temperature and the period of exposure to warming or cooling; it rises when the acclimation temperature increases, then reaches a threshold value. This threshold value is generally termed the Ultimate Incipient Lethal Temperature (UILT) while the lethal temperatures in the phase of dependence on acclimation temperature are called the Incipient Lethal Temperature (ILT). We must recall that these thermal variables are LT50 values.

\section{Significance of critical and lethal temperatures}

Depending on the experimental way in which they are determined, these variables represent a thermal stress which is lethal (lethal temperature) or sublethal (critical temperature). In one case, the thermal stress causes irreversible damage resulting in death; in the other, warming causes uncoordinated movements which cease when the fish is returned to water at the acclimation temperature. In both cases, therefore, it is a question not of physiological effects over the long term due to an oxygen deficit or to degradation of the global energy balance, but rather of rapid reactions to the variation in temperature, leading in the short term to a physiological disorder.

Figure 1a shows three regions:

- the zone of thermal tolerance, compatible with survival of the fish;

- the zone of thermal resistance;

- the zone of instantaneous mortality.

\section{> METHODOLOGY ADOPTED BY THE AUTHORS}

We opted to synthesize all data collected on thermal tolerances of the species, proposing two temperature ranges characteristic of each life stage when sufficient data was available (Figure 1b):

- a range of optimum temperatures corresponding to the range in which most data mentioned in the literature under this name fall;

- an expanded range of optimum temperatures corresponding to the extreme minimum and maximum temperatures tolerated, whose limits correspond to those of the range of resistance defined above. This range is limited by CT max values established in the laboratory when they exist. For the embryo stage, it is often the lethal temperature (the boundary temperatures between the optimum and lethal temperature are difficult to measure).

Generally speaking, data from observations described in original paper were preferred over compilations in the literature. Particular attention was also given to consistency in data, to establish the ranges for a given life stage and between different stages for a single species. When the data were sufficiently robust for the other life stages and insufficient for the juveniles 


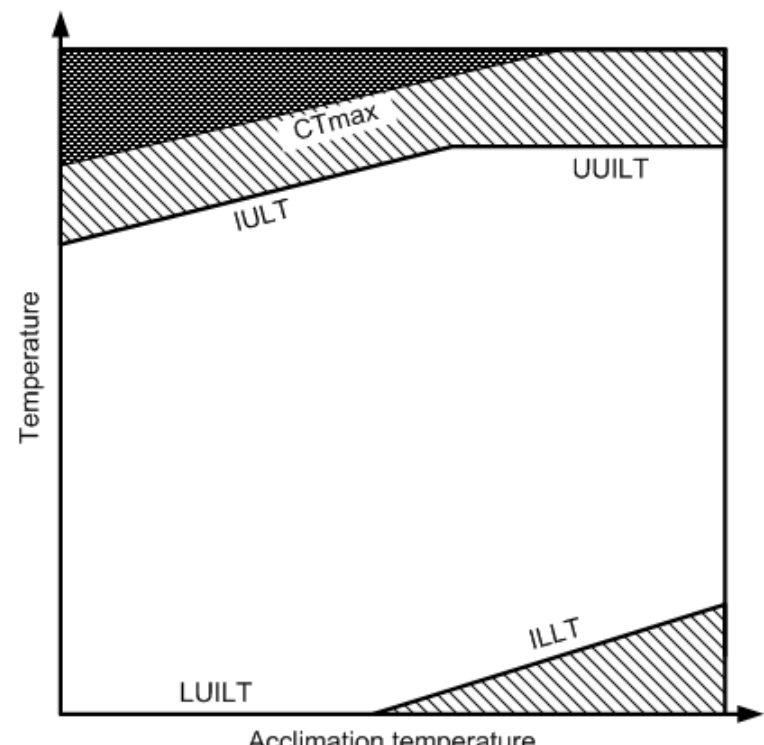

(a)

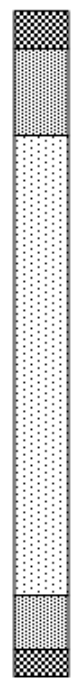

(b)

IULT : Incipient Upper Lethal Temperature UUILT : Upper Ultimate Incipient Lethal Temperature ILLT : Incipient Lower Lethal Temperature LUILT : Lower Ultimate Incipient Lethal Temperature CTmax : Maximum threshold established by CTM

\section{Tolerance range}

Resistance range

Instantaneous death range
Optimal range

\pm Resistance range

\section{Figure 1}

Different thermal variables (adapted from Beitinger et al., 2000b; Todd et al., 2008). (a) Different temperature variables versus acclimatation temperature, (b) synthetic range of temperature tolerance.

or adults of a single species, certain range boundaries were transposed from one stage to another, according to the following rules:

- juvenile range = adult range;

- optimum juvenile range $=$ extended larva range.

\section{> TEMPERATURE-RELATED PARAMETERS}

Fish species have habitat preferences which differ notably from one life stage to another. Because thermal preferences also differ according to the life stage, the parameters retained vary for each one. Each period in the life cycle of the fish is therefore examined independently. For the adult and juvenile stages, the temperatures optimum for life are inventoried. Boundary temperatures obtained in the laboratory (CTM or ILT experiments) are also generally available for these stages. Lastly, when mortality temperatures for individuals are observed in the field, they are mentioned.

For the embryo and the larva, we added the period in number of degree days for each of the two stages, with the associated water temperature when it was known.

The threshold temperatures for the beginning and end of reproduction are also useful parameters.

For each temperature datum found, some information about the corresponding study is systematically provided when it was given (location of the study, temperature recorded in situ 
or obtained from laboratory experiments, references to other studies). This information will later make it possible to compare values of a similar nature.

Among the different parameters found, some were given preference due to their ecological significance.

Within the range of optimum temperatures, the fish experiences no stress and lives without constraint. This datum is therefore essential to a good synthesis of thermal tolerances.

Among the experimental data found, the IULT for $24 \mathrm{~h}$ was preferred over data obtained with shorter periods of exposure. This is because the boundary temperatures obtained with shorter periods of exposure (for example 100 or $1000 \mathrm{~min}$ ) have consequences: the final phase of thermal stress described by Elliott (1981) is reached.

\section{> FISH SPECIES}

This synthesis bears on 19 fish species: those most commonly found in medium- to large streams (river order 5 or higher) in Western Europe. In-depth bibliographical research was conducted on their thermal tolerances. These 19 species of non-migratory fish are: vairone, sofie, nase, gudgeon, chub, dace, spirlin, barbel, bitterling, roach, bleak, bream, white bream, perch, ruffe, pike-perch, northern pike, pumpkinseed and catfish (Table I with scientific name).

\section{> OVERVIEW OF DATA COLLECTED}

Among the 390 references consulted and inventoried giving thermal tolerance data for the target fish species, close to 300 are quoted in this paper. Around one-quarter of those references are compilations of data (works on a general nature on freshwater fish or bibliographical summaries of studies of the temperature factor), and three-quarters are observations. Only $35 \%$ of the temperatures found were obtained from laboratory experiments (65\% come from field studies).

Table II summarizes the number of data collected (of all types) for the different life stages of the 19 target species in this paper. An optimum temperature range is considered as a single datum when it appears in a single reference.

Generally speaking, the thermal tolerances of the different life stages of a fish are not studied in uniform fashion: the larval and juvenile stages are very little documented in comparison with the others. Data on the embryo stage is extremely heterogeneous depending on the species, while the adult and reproduction stages are the most studied in the life cycle, in terms of temperature. Despite the efforts of researchers, there are four species, each characterized by fewer than ten data, for which information is very limited in terms of thermal tolerance: these are the vairone, sofie, bitterling and white bream (Table II, in gray).

\section{RESULTS}

The thermal tolerance data collected for each stage in the life cycle of each species are commented on below and presented in full in Appendix. The species are classified by family in accordance with their theoretical longitudinal zonation in streams (Verneaux, 1981). Optimum temperature ranges and broader ranges whose extreme limits correspond to those of the zone of resistance are proposed for each life stage when the data exist or can reasonably be estimated (see the methodology adopted by the authors in paragraph 1.4).

\section{> CYPRINIDAE FAMILY}

\section{Western Vairone (Telestes souffia)}

The embryo stage of the western vairone is estimated at 7 days at $13.9{ }^{\circ} \mathrm{C}$ by Bohl et al. (2004). These same authors (Bohl et al., 2004) keep western vairone embryos in an aquarium at between $13.9^{\circ} \mathrm{C}$ and $18.5^{\circ} \mathrm{C}$. 
Table II

Summary of the number of data for each species life stage (classified according to Verneaux typology, 1981).

\begin{tabular}{|l|c|c|c|c|c|c|}
\hline Species & Embryo & Larva & Juvenile & Adult & $\begin{array}{c}\text { Spawning } \\
\text { (tgametogenesis })\end{array}$ & TOTAL \\
\hline Vairone & 1 & 0 & 2 & 2 & 3 & 8 \\
\hline Sofie & 1 & 1 & 0 & 2 & 5 & 9 \\
\hline French nase & 12 & 6 & 1 & 2 & 14 & 35 \\
\hline Gudgeon & 3 & 1 & 1 & 11 & 7 & 23 \\
\hline Chub & 12 & 8 & 1 & 5 & 5 & 31 \\
\hline Dace & 21 & 4 & 1 & 1 & 17 & 44 \\
\hline Spirlin & 3 & 2 & 0 & 2 & 7 & 14 \\
\hline Barbel & 15 & 3 & 4 & 3 & 9 & 34 \\
\hline Bitterling & 0 & 0 & 0 & 3 & $4(+1)$ & 3 \\
\hline Roach & 5 & 2 & 10 & 12 & 15 & 44 \\
\hline Bleak & 1 & 1 & 0 & 4 & 7 & 13 \\
\hline Common bream & 8 & 2 & 1 & 9 & 13 & 33 \\
\hline White bream & 2 & 0 & 0 & 2 & 5 & 9 \\
\hline Eurasian perch & 11 & 8 & 6 & 18 & 16 & 59 \\
\hline Ruffe & 6 & 2 & 3 & 2 & $8(+1)$ & 13 \\
\hline Pike perch & 10 & 4 & 2 & 5 & 13 & 34 \\
\hline Northern perch & 10 & 3 & 3 & 11 & 14 & 41 \\
\hline Pumpkinseed & 1 & 2 & 3 & 18 & 4 & 28 \\
\hline Catfish & 4 & 2 & 0 & 9 & 8 & 23 \\
\hline TOTAL & 126 & 51 & 38 & 121 & 162 & 498 \\
\hline In grey: Species for & (1) & 1 & & \\
\hline
\end{tabular}

In grey: Species for which less than 10 data were found.

The optimum temperature for the juvenile stage appears to lie between $13^{\circ} \mathrm{C}$ and $15^{\circ} \mathrm{C}$ with an extreme minimum temperature of $10^{\circ} \mathrm{C}$ (Bohl et al., 2004).

For the adult stage, the optimum is between $10^{\circ} \mathrm{C}$ and $18^{\circ} \mathrm{C}$ (Ginot et al., 1996; Fishbase), with extremes of $1.9^{\circ} \mathrm{C}$ to $4{ }^{\circ} \mathrm{C}$ for the minimum temperature (Bohl et al., 2004) and $27^{\circ} \mathrm{C}$ for the maximum (Stankovitch, 1921; Ginot et al., 1996).

Lastly, reproduction occurs between $12^{\circ} \mathrm{C}$ (Natura 2000) and $15^{\circ} \mathrm{C}$ (Bohl et al., 2004), with an extreme maximum temperature estimated at $19^{\circ} \mathrm{C}$ (Bohl et al., 2004). Spillmann (1962 in Schwarz, 1996) mentions a lower maximum between $11^{\circ} \mathrm{C}$ and $13^{\circ} \mathrm{C}$.

\section{Sofie (Chondrostoma toxostoma)}

Spillmann (1961) estimates that the sofie embryo hatches between 12 and 15 days after egglaying (but specifies no temperature). Gozlan et al. (1999) mention breeding sofie in an aquarium at $6{ }^{\circ} \mathrm{C}$ with an incubation period of 8 days.

The latter authors (Gozlan et al., 1999) observed larval growth in the natural environment at temperatures ranging between $14^{\circ} \mathrm{C}$ and $18^{\circ} \mathrm{C}$.

The range of optimum temperatures for the adult stage falls between $16{ }^{\circ} \mathrm{C}$ and $25^{\circ} \mathrm{C}$ (Gozlan, 1998). 
Bruslé and Quignard (2001) estimate the reproduction optimum between $9{ }^{\circ} \mathrm{C}$ and $11^{\circ} \mathrm{C}$ while Perche (1948 in the Doubs basin, France, in Spillmann, 1961) and Lelek (1987) mention an onset of reproduction at $13^{\circ} \mathrm{C}$. The Natura 2000 data sheet on the species places reproduction at temperatures between these two values, between $11^{\circ} \mathrm{C}$ and $13^{\circ} \mathrm{C}$, on the lower stretch of the Verdon, south-east France. It appears to be accepted by ichthyologists that the temperature preferenda for the sofie are close to those of the French nase, i.e. between $8^{\circ} \mathrm{C}$ and $14{ }^{\circ} \mathrm{C}$. However, Chappaz et al. (1989 in Maier et al., 1995) observed spawning in the Verdon one month later than for the French nase, i.e. between the end of May and the beginning of June. Optimum temperatures for reproduction appear therefore to lie between $9{ }^{\circ} \mathrm{C}$ and $14{ }^{\circ} \mathrm{C}$ for the sofie.

\section{Nase (Chondrostoma nasus)}

Optimum temperatures for development of the nase embryo lie between $10^{\circ} \mathrm{C}$ (Penáz, $1974 \mathrm{~b}$ in the Czech Republic) and $17^{\circ} \mathrm{C}$ (Müller, 1997 in Küttel et al., 2002); four references give optima in this range (Penáz, 1974b; Lusk, 1995 in the Czech Republic; Herzig and Winkler, 1985 in Küttel et al., 2002; Keckeis et al., 2001 in Austria, in Schiemer et al., 2003). The extreme temperatures tolerated are, for the most part, estimated between $8{ }^{\circ} \mathrm{C}$ (Prokes and Penáz, 1978; Kamler et al., 1998) and $19^{\circ} \mathrm{C}$ (Schiemer et al., 2004) with one lethal temperature put by Kamler et al. (1998 in Kamler, 2002) at $20^{\circ} \mathrm{C}$.

Herzig and Winkler (1986) established an equation linking the period of incubation ( $D$ in days, $50 \%$ of hatches) to temperature $\left(T\right.$ in $\left.{ }^{\circ} \mathrm{C}\right)$ :

$$
D=1258 /(T-2.62)^{1.994}
$$

or, 23.1 days at $10^{\circ} \mathrm{C}$ and 5.8 days at $17^{\circ} \mathrm{C}$, the range of validity of the equation.

For the larvae, the optimum temperature lies between $15^{\circ} \mathrm{C}$ (Kamler et al., 1998; Penáz, 1974a in Schiemer et al., 2003 on the Danube) and $25^{\circ} \mathrm{C}$ (Keckeis et al., 2001; Schiemer et al., 2004). The maximum tolerated is on the order of $28^{\circ} \mathrm{C}$ (Penáz, 1974a in Schiemer et al., 2003 on the Danube; Schiemer et al., 2003; Spurny et al., 2004 in Wolnicki and Gorni, 1994), a datum found in two articles (Wolnicki and Gorni, 1994; Schiemer et al., 2003). The larvae also appears to tolerate temperatures up to $10^{\circ} \mathrm{C}$ (Schiemer et al., 2004).

In view of fishing results on the Rhône, Ginot et al. (1996) establish optimum temperatures for nase juveniles between $7{ }^{\circ} \mathrm{C}$ and $27^{\circ} \mathrm{C}$. It seems more realistic to put these temperatures within a more limited range, comparable to that for the embryo, between $15^{\circ} \mathrm{C}$ and $25^{\circ} \mathrm{C}$ (Kamler et al., 1998; Penáz, 1974b in Schiemer et al., 2003, 2004; Teletchea et al., 2009b).

Bruslé and Quignard (2001) are the only authors to define thermal tolerance thresholds for the adult: they consider that the range of temperatures within which the adult feeds is between $4{ }^{\circ} \mathrm{C}$ and $24^{\circ} \mathrm{C}$. We believe, however, that the minimum optimum can reasonably be put higher, on a level with that for the juvenile, around $15^{\circ} \mathrm{C}$.

Most authors place the optimum temperature range for reproduction of the nase between $8{ }^{\circ} \mathrm{C}$ and $14{ }^{\circ} \mathrm{C}$ (Banarescu, 1964; Prokes and Penáz, 1978; Philippart, 1980; Penáz et al., 1995; Poncin, 1996; Bruslé and Quignard, 2001; Keckeis et al., 2001; Penáz, 1974b in Schiemer et al., 2004; Teletchea et al., 2009b). The extreme temperatures allowing for reproduction are on the order of $6{ }^{\circ} \mathrm{C}$ for the minimum (Filipi, 1962 in Albania; Lusk, 1967; Herzig and Winkler, 1985 in Küttel et al., 2002) and $16{ }^{\circ} \mathrm{C}$ for the maximum (Alabaster and Lloyd, 1982; Herzig and Winkler, 1985 in Küttel et al., 2002).

\section{Gudgeon (Gobio gobio)}

The period of embryonic development has been estimated in the laboratory at between 6.3 days at $20^{\circ} \mathrm{C}$ (Brunet and Hoestlandt, 1972) and 6.9 days at $18.5^{\circ} \mathrm{C}$, or approximately 125 degree days, which is confirmed by Teletchea et al. (2009b). The optimum temperature range lies between $16^{\circ} \mathrm{C}$ and $20^{\circ} \mathrm{C}$ (Tocko, 1987 in Banarescu et al., 2003b).

Teletchea et al. (2009b) estimate the optimum temperature for the larva at $20.5^{\circ} \mathrm{C}$. 
Ginot et al. (1996) found optimum temperatures for the juvenile stage between $7{ }^{\circ} \mathrm{C}$ and $27^{\circ} \mathrm{C}$ on the Rhône.

The most information available for the gudgeon bears on the adult stage: its lower optimum temperature has been put at $7{ }^{\circ} \mathrm{C}$ (Ginot et al., 1996 on the Rhône) and its upper boundary temperature at $30^{\circ} \mathrm{C}$ (Kryzhanovskii, 1949 in Alabaster and Lloyd, 1982; Elliott, 1981 in Küttel et al., 2002). Three other references suggest a more restricted range (Bernet, 1960 on the Nivelle, France in Hynes, 1970; Bruslé and Quignard, 2001; Banarescu et al., 2003a). Horoszewicz (1973 in Alabaster and Lloyd, 1982) found a lethal temperature of $36.7^{\circ} \mathrm{C}$ in field experiments in Poland, in a dammed reservoir at $25.5^{\circ} \mathrm{C}$ (sublethal threshold reached at $30.8-30.9^{\circ} \mathrm{C}$ ). Kryzhanovskii (1949 in Alabaster and Lloyd, 1982) gives the same lethal temperature. The authors therefore chose $36^{\circ} \mathrm{C}$ as being the upper maximum temperature tolerated by this stage. The extreme lower temperature appears to be around $5^{\circ} \mathrm{C}$ (Banarescu, 1964). Four authors conducted laboratory tests to identify the boundary temperatures. The IULT temperatures mentioned fall between $27.2^{\circ} \mathrm{C}$ (Alabaster, 1964) and $30^{\circ} \mathrm{C}$ (Varley, 1967 in Küttel et al., 2002) depending on the author and the acclimation temperature. Kraiem and Pattee (1980) also recorded a LC50 for dioxygen of $1.8 \mathrm{mg} \cdot \mathrm{L}^{-1}$ at $20^{\circ} \mathrm{C}\left(\mathrm{LC}\right.$ over $24 \mathrm{~h}$ of $\left.1.9 \mathrm{mg} \cdot \mathrm{L}^{-1}\right)$ and a CT max of $30^{\circ} \mathrm{C}$ at $20^{\circ} \mathrm{C}$. This boundary temperature appears low in view of the optima mentioned in other references, and it was therefore not retained as the extreme temperature tolerated.

A few data on the temperatures at the beginning of reproduction are given, particularly in summaries of the literature (Kennedy and Fitzmaurice, 1972; Alabaster and Lloyd, 1982): the minimum optimum stands at $12{ }^{\circ} \mathrm{C}$ (Elliott, 1981; Kryzhanovskii, 1949 in Alabaster and Lloyd, 1982; Mann, 1996) and the maximum at around $17^{\circ} \mathrm{C}$ (Bourgeois, 1964 in Kennedy and Fitzmaurice, 1972; Mann, 1996). Banarescu (2003b) mentions an extreme maximum temperature for reproduction of $24^{\circ} \mathrm{C}$.

\section{Chub (Leuciscus cephalus)}

For the chub embryo, Elliott (1981 in Küttel et al., 2002) and Alabaster and Lloyd (1982) find a lower optimum temperature of $16{ }^{\circ} \mathrm{C}$, the higher optimum being $24^{\circ} \mathrm{C}$ for Alabaster and Lloyd (1982) in a heated lake. Both authors agree on a maximum tolerated temperature of $30^{\circ} \mathrm{C}$ (Alabaster and Lloyd, 1982 find this value in situ), which is consistent with the $29^{\circ} \mathrm{C}$ found by Mamcarz et al. (2005) in the laboratory. The lower lethal temperature in the laboratory is $9.5^{\circ} \mathrm{C}$ for Mamcarz et al. (2005). Ten data provided by seven authors refer to the period between egg-laying and hatching; they range between 1.5 days at $27.5^{\circ} \mathrm{C}$ (Kupren et al., 2008) and 9 days at $12.3^{\circ} \mathrm{C}$ (Mamcarz et al., 2005).

The optimum temperature range for the larva lies between $14{ }^{\circ} \mathrm{C}$ (Penáz and Sterba, 1969) and $25^{\circ} \mathrm{C}$ (Wolnicki and Myszkowski, 1999; Kwiatkowski et al., 2008), according to three references (Shiri Harzevili et al., 2003; Teletchea et al., 2009b; Fishbase). All data used to establish this range come from laboratory experiments. Philippart et al. (1989) evaluate the time between egg-laying and hatching of the larval stage at 150 degree days, a value much lower than the 21 days at $25^{\circ} \mathrm{C}$ proposed by two authors (Kwiatkowski et al., 2008; Zarski et al., 2008).

The optimum range for the juvenile is considered to be the same as for the larva, which corresponds well to the tolerances found on the Rhône (Ginot et al., 1996). The maximum upper boundary is taken as identical to that for the adult $\left(30^{\circ} \mathrm{C}\right)$.

The optimum range of temperatures for the adult stage is estimated between $14{ }^{\circ} \mathrm{C}$ and $24^{\circ} \mathrm{C}$ (Ginot et al., 1996 on the Rhône; Cowx and Welcomme, 1998). The extreme minimum temperature is around $8{ }^{\circ} \mathrm{C}$ and the extreme maximum, $30^{\circ} \mathrm{C}$ (Elliott, 1981; Alabaster and Lloyd, 1982). On the basis of two findings of Horoszewicz (1973 in Alabaster and Lloyd, 1982) in Polish dammed lakes which warmed by $6^{\circ} \mathrm{C}$ per hour, the lethal temperature has been established at $37.9^{\circ} \mathrm{C}$ (acclimation at $25.7^{\circ} \mathrm{C}$ ) and $38.8^{\circ} \mathrm{C}$ (acclimation at $30.8^{\circ} \mathrm{C}$ ).

The optimum temperatures for reproduction lie between $15^{\circ} \mathrm{C}$ and $20^{\circ} \mathrm{C}$ (Kucharczyk et al., 2008 in laboratory). 


\section{Dace (Leuciscus leuciscus)}

There is abundant data available for the embryo stage of the dace (Wurtz-Arlet, 1950; Mills, 1980; Kennedy, 1969 in Wüstemann and Kammerad, 1995; Herzig and Winkler, 1985 in Küttel et al., 2002; Cowx and Welcomme, 1998; Bruslé and Quignard, 2001; Mamcarz et al., 2005; Kupren et al., 2008; Teletchea et al., 2009b). In the laboratory, the dace embryo does not appear able to survive below $4{ }^{\circ} \mathrm{C}$ (Herzig and Winkler, 1985 in Küttel et al., 2002; Mamcarz et al., 2005; Mills, 1980), the optimum temperature range being $7-15^{\circ} \mathrm{C}$ (Mills, 1991 in Küttel et al., 2002; Mamcarz et al., 2005), with a maximum optimum of $23^{\circ} \mathrm{C}$ and a lethal temperature estimated experimentally by Mamcarz et al. (2005) at $25^{\circ} \mathrm{C}$. We should nonetheless note that Mills (1980) finds that growth stops at $16.5^{\circ} \mathrm{C}$ in the laboratory.

The period of incubation is summed up in Mills' equation (1980), based on laboratory experiments: $D=96.59-9.3 T+0.254 T^{2}$

or, 46 days at $6.75^{\circ} \mathrm{C}, 32$ days at $8.8^{\circ} \mathrm{C}, 30$ days at $10^{\circ} \mathrm{C}, 12$ days at $16.5^{\circ} \mathrm{C}$.

For the larva, the optimum temperature range appears to fall between $16^{\circ} \mathrm{C}$ (Lepičová et al., 2002) and $25^{\circ} \mathrm{C}$ (Herzig and Winkler, 1985; Kwiatkowski et al., 2008). Teletchea et al. (2009b) propose a maximum temperature of $12{ }^{\circ} \mathrm{C}$.

For the juvenile and adult, Wüstemann and Kammerad (1995) give tolerated temperatures between $4{ }^{\circ} \mathrm{C}$ and $22{ }^{\circ} \mathrm{C}$, an optimum range between $10^{\circ} \mathrm{C}$ and $20^{\circ} \mathrm{C}$ and a lethal temperature of $32^{\circ} \mathrm{C}$. This lethal temperature depends on the dissolved oxygen concentration. The same authors (Wüstemann and Kammerad, 1995) measured a dioxygen $\mathrm{LC}$ for the adult dace of $3.2 \mathrm{mg} \cdot \mathrm{L}^{-1}$ for $24 \mathrm{~h}$ at $20^{\circ} \mathrm{C}$ (dace do not survive long with this concentration). The range of optimum temperatures for the juvenile is considered identical to the extended range for the larva $\left(12-25^{\circ} \mathrm{C}\right)$. The maximum optimum for the adult is also set at $25^{\circ} \mathrm{C}$.

For dace, reproduction is preferentially at temperatures between $7{ }^{\circ} \mathrm{C}$ (Mann, 1974; Philippart, 1981; Millet, 1989) and $12^{\circ} \mathrm{C}$ (Mann, 1996; Kucharczyk et al., 2008); seven references give optimum temperatures between these limits (Kennedy, 1969; Lelek, 1987; Philippart et al., 1989; Bourgeois, 1963 in France, in Wüstemann and Kammerad, 1995; Poncin, 1996 on the Meuse, Belgium; Herzig and Winkler, 1985 in the laboratory, in Küttel et al., 2002; Teletchea et al., 2009b). It apparently remains possible between $5^{\circ} \mathrm{C}$ (Alabaster and Lloyd, 1982; Mann, 1996; Kucharczyk et al., 1998) and $16.5^{\circ} \mathrm{C}$ (Mills, 1980 in Millet, 1989 in the laboratory).

\section{Spirlin (Alburnoides bipunctatus)}

The period of incubation for the spirlin is around 100 degree days (Spillmann, 1961; Bless, 1996 who recorded 5.2 days at $19.3^{\circ} \mathrm{C}$; Bohl et al., 2004).

The optimum temperature range for the larval stage is between $19^{\circ} \mathrm{C}$ and $24^{\circ} \mathrm{C}$ (Alabaster and Lloyd, 1982), $12{ }^{\circ} \mathrm{C}$ being the lower value (Bless, 1996).

The optimum for the juvenile $\left(12-24^{\circ} \mathrm{C}\right)$ is taken as the extended optimum temperature range for the larva.

Only extreme temperatures are given for the adult spirlin: they fall between $1.9^{\circ} \mathrm{C}$ and $24^{\circ} \mathrm{C}$ (Bohl et al., 2004), with a lethal temperature of around $27^{\circ} \mathrm{C}$ in situ in Switzerland (Breitenstein and Kirchhofer, 1999). The range of optimum temperatures would appear then, as for the larva and juvenile, to lie between $12^{\circ} \mathrm{C}$ (minimum optimum adopted for the juvenile on the basis of the extreme minimum for the larva) and $24^{\circ} \mathrm{C}$.

Some references give optimum temperatures for reproduction: they fall between $14{ }^{\circ} \mathrm{C}$ (Pelz, 1986 in Breitenstein and Kirchhofer, 1999; Mann, 1996 in Breitenstein and Kirchhofer, 1999) and $21^{\circ} \mathrm{C}$ (Bohl et al., 2004), with two references that give optima within this range (Holcik and Hensel, 1971 in Papadopol and Cristofor, 1980; Philippart et al., 1989). The extreme temperatures allowing for reproduction were observed to be between $12{ }^{\circ} \mathrm{C}$ (Bless, 1996 in the laboratory; Keith and Allardi, 2001) and $25^{\circ} \mathrm{C}$ (Yildirim et al., $1999 \mathrm{in}$ Turkey). The spirlin is a fish with a staggered egg-laying period, which explains the temperature range during which reproduction is possible. 


\section{Barbel (Barbus barbus)}

Thermal tolerances for the barbel embryo are widely documented (thanks in particular to syntheses by Krupka, 1988; Kamler, 2002; Küttel et al., 2002). The optimum temperature according to most authors falls between $16{ }^{\circ} \mathrm{C}$ and $21^{\circ} \mathrm{C}$ (Kraiem and Pattee, 1980; Penáz, 1973 in Kamler, 2002; Herzig and Winkler, 1985 in Küttel et al., 2002). Only Baras (1995 in Bruslé and Quignard, 2001) notes a lower optimum of $13^{\circ} \mathrm{C}$. Penáz (1973 in Kamler, 2002) found that growth stopped below $12{ }^{\circ} \mathrm{C}$ and Elliott (1981 in Küttel et al., 2002), above $20^{\circ} \mathrm{C}$. Krupka (1988) lists six periods between egg-laying and hatching, observed in different studies (Gyurko et al., 1957 in Romania; Penáz, 1973; Krupka, 1988): they range between 3.7 days (Krupka, 1988) and 8 days (Penáz, 1973) at temperatures of $20.2^{\circ} \mathrm{C}$ and $16{ }^{\circ} \mathrm{C}$ respectively. These values correspond relatively well to those given by Cowx and Welcomme (1998) ( 11 days at $14^{\circ} \mathrm{C}$ and $5-6$ days at $19^{\circ} \mathrm{C}$ ), by Poncin (1996) on the Belgian Meuse (3-4 days at $20^{\circ} \mathrm{C}$ ) and by Teletchea et al. (2009b) in the laboratory (5.6 days at $\left.17.5^{\circ} \mathrm{C}\right)$.

The various authors who have studied the larval stage in the laboratory bred barbel at temperatures between $14.8^{\circ} \mathrm{C}$ and $18.9^{\circ} \mathrm{C}$ (Vladimirov and Bodareu, 1975 in Banarescu, 2003a; Teletchea et al., 2009b). The extreme temperature tolerated in the laboratory can reach $24.5^{\circ} \mathrm{C}$ (Bodareu and Karlov, 1984 in Banarescu, 2003a). Krupka (1988) estimates the duration of the larval stage at 12.6 days at $20.2^{\circ} \mathrm{C}$.

Baras and Philippart (1999) have shown that growth in juvenile barbel ceases below a temperature of $13.5^{\circ} \mathrm{C}$ on the Ourthe in Belgium. Ginot et al. (1996) sampled active barbel between $7{ }^{\circ} \mathrm{C}$ and $27^{\circ} \mathrm{C}$ on the Rhône. The range of optimum temperatures therefore appears to fall between $13^{\circ} \mathrm{C}$ and $24^{\circ} \mathrm{C}\left(24^{\circ} \mathrm{C}\right.$ corresponding to the upper boundary for the larva). Kraiem and Pattee (1980) conducted several experiments in the laboratory on barbel juveniles, allowing them to estimate a CT maximum of $31.5^{\circ} \mathrm{C}$ (chosen as the upper boundary temperature tolerated by this stage) and an IULT over $24 \mathrm{~h}$ of $30^{\circ} \mathrm{C}$ for acclimation for 10 days at $20^{\circ} \mathrm{C}$ (at this temperature, they found a LC for dioxygen of $2.1 \mathrm{mg} \cdot \mathrm{L}^{-1}$ for $24 \mathrm{~h}$, with an LC50 of $2 \mathrm{mg} \cdot \mathrm{L}^{-1}$ ) and an IULT over $24 \mathrm{~h}$ of $29.7^{\circ} \mathrm{C}$ for acclimation at $16^{\circ} \mathrm{C}$.

Optimum temperatures for the adult stage range between $10^{\circ} \mathrm{C}$ and $24^{\circ} \mathrm{C}$ (Leynaud and Allardi, 1974 on the Seine; Ginot et al., 1996 on the Rhône; Fishbase). The maximum temperature tolerated was set at $32{ }^{\circ} \mathrm{C}$, by analogy with the juvenile (Kraiem and Pattee, 1980).

Barbel reproduces preferentially at temperatures between $13.5^{\circ} \mathrm{C}$ (Prignon et al., 1988; Baras and Philippart, 1999; Elliott, 1981 in Küttel et al., 2002) and $20^{\circ} \mathrm{C}$ (Mann, 1996; Elliott, 1981 in Küttel et al., 2002), though reproduction can begin at $8{ }^{\circ} \mathrm{C}$ (1985 in Küttel et al., 2002) and continue up to $25^{\circ} \mathrm{C}$ (Banarescu et al., 2003a) and even $29^{\circ} \mathrm{C}$ (Alabaster and Lloyd, 1982).

\section{Bitterling (Rhodeus sericeus)}

Wohlgemuth (1981) estimates the optimum temperature range for the adult bitterling at between $12{ }^{\circ} \mathrm{C}$ and $24.3^{\circ} \mathrm{C}$ and Zahn (1963 in Jobling, 1981) extended it up to $30^{\circ} \mathrm{C}$. The lethal temperature in a warmed lake in Poland was put at $37^{\circ} \mathrm{C}$ (Horosewicz, 1971 in Jobling, 1981).

In different summaries listed by Duyvené de Wit (1955), the optimum for reproduction in bitterling lies between $15^{\circ} \mathrm{C}$ and $21^{\circ} \mathrm{C}$ (Holcik, 2003; Natura 2000), with extremes of $12{ }^{\circ} \mathrm{C}$ and $26.2^{\circ} \mathrm{C}$ (Tarkan et al., 2005; Konecná et al., 2009). Bruslé and Quignard (2001), however, find that the water temperature must be between $13-22{ }^{\circ} \mathrm{C}$ for gametogenesis to occur.

\section{Roach (Rutilus rutilus)}

For the roach embryo stage, Gulidov and Popova (1981 in Gillet, 1989) found a range of optimum temperatures between $12^{\circ} \mathrm{C}$ and $24^{\circ} \mathrm{C}$; as for the lethal temperature, Horosewicz (1971 in Nzau Matondo et al., 2007) estimates it at $26^{\circ} \mathrm{C}$ in a warmed lake in Poland. Teletchea et al. (2009b) give a period between egg-laying and hatching of 7.4 days at $15.5^{\circ} \mathrm{C}$ and Cowx and Welcomme (1998) put it at 11 to 12 days at $12.9^{\circ} \mathrm{C}$ and 30 days at $7^{\circ} \mathrm{C}$. 
The Fishbase website and Teletchea et al. (2009b) give an identical optimum temperature for the roach larval stage: $17.5^{\circ} \mathrm{C}$.

Ginot et al. (1996) found optimum temperatures for juveniles between $7{ }^{\circ} \mathrm{C}$ and $21^{\circ} \mathrm{C}$ on the Rhône. Barbier and Pascal (1976) conducted experiments on roach juveniles, at nine acclimation temperatures (from $14.2{ }^{\circ} \mathrm{C}$ to $34^{\circ} \mathrm{C}$ ). They found IULT values over $24 \mathrm{~h}$ ranging between $26.9^{\circ} \mathrm{C}$ and $34.7^{\circ} \mathrm{C}$, with most falling around $30^{\circ} \mathrm{C}$, which is considered to be the maximum upper boundary tolerated.

For the adult roach, Elliott (1994) finds optimum temperatures over an extremely wide range: $12{ }^{\circ} \mathrm{C}$ for the minimum and $25^{\circ} \mathrm{C}$ for the maximum. Two authors added to these optimum temperatures with experiments conducted in the laboratory in England. For acclimation temperatures of $15^{\circ} \mathrm{C}, 20^{\circ} \mathrm{C}$ and $25^{\circ} \mathrm{C}$, Alabaster (1964) recorded respective IULT values after $1000 \mathrm{~min}$ of $27.3^{\circ} \mathrm{C}, 29.4^{\circ} \mathrm{C}$ and $31.5^{\circ} \mathrm{C}$. Cocking (1959) found upper lethal temperatures between $30.1^{\circ} \mathrm{C}$ and $35.2^{\circ} \mathrm{C}$ in the course of seven experiments (acclimation varying from $17^{\circ} \mathrm{C}$ to $33^{\circ} \mathrm{C}$ ) and the lowest ILLT, at $7{ }^{\circ} \mathrm{C}$, for acclimation at $23^{\circ} \mathrm{C}$. The upper boundary tolerated is $31^{\circ} \mathrm{C}$ according to Cocking (1959) (IULT maximum of $20^{\circ} \mathrm{C}$ ).

The optimum temperature for roach reproduction lies between $10^{\circ} \mathrm{C}$ (L'Abbée-Lund and Vøllestad, 1985 in Gillet, 1989 in Scandinavia; Easton and Dolben, 1980 in Gillet and Quétin, 2006) and $18{ }^{\circ} \mathrm{C}$ (Spillmann, 1961; Holcik and Hruska, 1966 in Gillet and Quétin, 2006); this range is confirmed by seven references to optimum temperatures (Easton and Dolben, 1980 in Gillet, 1989; Mills, 1981 in Gillet, 1989; Elliott, 1994; Poncin, 1996; Diamond, 1985 in the UK in Gillet and Quétin, 2006; Teletchea et al., 2009b). The lower boundary temperature given is around $7{ }^{\circ} \mathrm{C}$ (Mann, 1996; Noges and Jarvet, 2005 in Estonia) and the upper boundary temperature around $22^{\circ} \mathrm{C}$ (Gillet and Quétin, 2006 on Lake Geneva).

\section{Bleak (Alburnus alburnus)}

Only Alabaster and Lloyd (1982) have studied the embryo stage of the bleak, calculating a minimum CT of $14{ }^{\circ} \mathrm{C}$ and a maximum CT of $31^{\circ} \mathrm{C}$ (the limits of the extended range of maximum and minimum temperatures tolerated) for a range of optimum temperatures between $21^{\circ} \mathrm{C}$ and $27^{\circ} \mathrm{C}$. Spillmann (1961) estimates the period required between egg-laying and hatching of larvae between 14 and 21 days.

According to Fishbase, the optimum temperature for the bleak larva is around $22.5^{\circ} \mathrm{C}$.

For the adult stage, the optimum is unsure: Elliott (1981 in Küttel et al., 2002) gives a value of around $30^{\circ} \mathrm{C}$, whereas it is around $20^{\circ} \mathrm{C}$ for Alabaster and Downing (1966 in Coutant, 1975). The lethal temperature was found by Horoszewicz (1973 in Alabaster and Lloyd, 1982) to be $37.7^{\circ} \mathrm{C}$ for acclimation at $25.7-26.2^{\circ} \mathrm{C}$ in a dammed lake whose temperature rises $6{ }^{\circ} \mathrm{C}$ per hour in Poland. The maximum tolerated is therefore probably slightly lower, no doubt around $35^{\circ} \mathrm{C}$.

Several references, both data compilations (Prokes and Penáz, 1978; Keith and Allardi, 2001) and field studies (Berg, 1949; Chappaz et al., 1987 on Lake Sainte Croix, South East France), place the onset of reproduction at $15^{\circ} \mathrm{C}$ and all authors agree on a maximum optimum temperature of $28^{\circ} \mathrm{C}$ (Alabaster and Lloyd, 1982; Statova, 1973 in Gillet, 1989; Mann, 1996; Keith and Allardi, 2001). The minimum tolerated for reproduction is $14{ }^{\circ} \mathrm{C}$ (Alabaster and Lloyd, 1982).

\section{Common bream (Abramis brama)}

The range of optimum temperatures for the embryo of the common bream lies between $12{ }^{\circ} \mathrm{C}$ (Herzig and Winkler, 1986 in Küttel et al., 2002) and $23^{\circ} \mathrm{C}$ (Alabaster and Lloyd, 1982). The lower boundary found is around $8-9^{\circ} \mathrm{C}$ (Alabaster and Lloyd, 1982; Elliott, 1981 in Küttel et al., 2002) while the lower lethal temperature recorded in the laboratory is $5{ }^{\circ} \mathrm{C}$ (Herzig and Winkler, 1986 in Küttel et al., 2002). The upper boundary is set at $28^{\circ} \mathrm{C}$ (Elliott, 1981 in Küttel et al., 2002) with a lethal temperature of $32^{\circ} \mathrm{C}$ (Herzig and Winkler, 1986 in Küttel et al., 2002). Bruslé and Quignard (2001) estimate the period between egg-laying and hatching at 9 days at 
$20^{\circ} \mathrm{C}$ and 10 days at $18^{\circ} \mathrm{C}$, as against 5.8 days at $20^{\circ} \mathrm{C}$ for Keith and Allardi (2001) and 7.5 days at $18{ }^{\circ} \mathrm{C}$ for Cowx and Welcomme (1998). At $16.5^{\circ} \mathrm{C}$, Teletchea et al. (2009b) estimate it at 6.4 days.

According to Fishbase, the optimum temperature for larvae is $17.5^{\circ} \mathrm{C}$. Teletchea et al. (2009b) place it rather at $19.5^{\circ} \mathrm{C}$.

For the juvenile stage, the extended optimum range is between $14{ }^{\circ} \mathrm{C}$ and $34{ }^{\circ} \mathrm{C}$ (Kucharczyk et al., 1998 in Küttel et al., 2002). We believe that the maximum optimum should be lower, around $28^{\circ} \mathrm{C}$.

The optimum range for the adult falls between $10^{\circ} \mathrm{C}$ (Fishbase) and $26^{\circ} \mathrm{C}$ (Müller, 1997 in Küttel et al., 2002), with extreme temperatures tolerated between $5^{\circ} \mathrm{C}$ (Holker, 2006) and $28^{\circ} \mathrm{C}$ (EIFAC, 1969 in Küttel et al., 2002). The upper lethal temperature was observed to be $35.7^{\circ} \mathrm{C}$ for acclimation at $25.7^{\circ} \mathrm{C}$ in a warmed lake in Poland (Horoszewicz, 1972). Several laboratory experiments also establish boundary temperatures. Alabaster (1964) recorded an IULT of $30.2{ }^{\circ} \mathrm{C}$ for 1000 minutes after acclimation at $20^{\circ} \mathrm{C}$. The synthesis drawn up by Küttel et al. (2002) lists maximum CT values of $35^{\circ} \mathrm{C}$ (Müller, 1997), considered to be the extreme maximum tolerated, and $36{ }^{\circ} \mathrm{C}$ (EIFAC, 1969). Finally, Alabaster and Downing (1966) recorded a maximum $\mathrm{CT}$ of $30.2{ }^{\circ} \mathrm{C}$ for acclimation at $20^{\circ} \mathrm{C}$.

The optimum range for reproduction for the common bream lies between $12{ }^{\circ} \mathrm{C}$ (Löffler, 1982; Mann, 1996; Bruslé and Quignard, 2001) and $20^{\circ} \mathrm{C}$ ( Mann, 1996; Poncin, 1996 on the Meuse; Keith and Allardi, 2001; Herzig and Winkler, 1985 in Küttel et al., 2002). The lower boundary temperature is estimated to be around $8{ }^{\circ} \mathrm{C}$ (EIFAC, 1969 in Küttel et al., 2002) and the upper boundary $28^{\circ} \mathrm{C}$ (Statova, 1973 in Gillet, 1989).

\section{White bream (Blicca bjoerkna)}

For the embryo stage of the white bream, the only datum collected comes from Cowx and Welcomme (1998), who estimate the time between egg-laying and hatching of larvae at 4 days at $20^{\circ} \mathrm{C}$ (and 5 days at $15^{\circ} \mathrm{C}$ ).

Observations on the Rhône show evidence of activity of white bream juveniles between $4{ }^{\circ} \mathrm{C}$ and $27^{\circ} \mathrm{C}$ (Ginot et al., 1996).

Cowx and Welcomme (1998) estimate the optimum range for the adult stage at between $16{ }^{\circ} \mathrm{C}$ and $25^{\circ} \mathrm{C}$. Brylinska and Zbikowska (1997) also place the optimum for adults within this range. On the Rhône at Bugey, Ginot et al. (1996) found temperatures tolerated between $4{ }^{\circ} \mathrm{C}$ and $27^{\circ} \mathrm{C}$.

The optimum for reproduction is between $15^{\circ} \mathrm{C}$ (Poncin, 1996 on the Meuse) and $25^{\circ} \mathrm{C}$ (Mann, 1996), with two authors placing the optimum temperature for adults in this range (Peczalska, 1979 in Brylinska and Zbikowska, 1997; Brylinska and Zbikowska, 1997). Reproduction is nonetheless possible between $9.6^{\circ} \mathrm{C}$ and $29^{\circ} \mathrm{C}$ in Russia (Roenko, 1965 in Brylinska and Zbikowska, 1997).

\section{>PERCIDAE FAMILY}

\section{Perch (Perca fluviatilis)}

The perch embryo stage is well documented: the broad range of optimum temperatures found is between $7{ }^{\circ} \mathrm{C}$ (Gillet, 1989) and $21^{\circ} \mathrm{C}$ (Hokanson and Kleiner, 1974; Wang and Eckmann, 1994 in Küttel et al., 2002) and the more limited range between $12^{\circ} \mathrm{C}$ (Alabaster and Lloyd, 1982; Wang and Eckmann, 1994 in Küttel et al., 2002) and $18^{\circ} \mathrm{C}$ (Alabaster and Lloyd, 1982; Saat and Veersalu, 1996). Five references give experimentally determined boundary temperatures (Alabaster and Lloyd, 1982; Hokanson, 1977 in Karas, 1996; Swift, 1965 in Küttel et al., 2002; Elliott, 1981 in Küttel et al., 2002; Wang and Eckmann, 1994 in Küttel et al., 2002): the minimum ILLT value is $6{ }^{\circ} \mathrm{C}$ (Hokanson, 1977 in Karas, 1996; Elliott, 1981; Wang and Eckmann, 1994 in Küttel et al., 2002) while the maximum is recorded at $26^{\circ} \mathrm{C}$ (Alabaster 
and Lloyd, 1982). Teletchea et al. (2009b) found a period of 13.2 days at $12.5^{\circ} \mathrm{C}$ between egglaying and hatching in the laboratory.

For the larva, the optimum temperature falls between $12^{\circ} \mathrm{C}$ (EIFAC, 1969 in Küttel et al., 2002) and $25^{\circ} \mathrm{C}$ (Karas, 1996). The lower boundary temperature is estimated at around $5{ }^{\circ} \mathrm{C}$, with another author giving optimum temperatures in this extended range (Karas, 1987 in Urho, 1996). Hokanson (1977 in Karas, 1996) found an IULT of $36^{\circ} \mathrm{C}$ and a CT maximum of $34{ }^{\circ} \mathrm{C}$, retained as the upper boundary temperature tolerated. Keith and Allardi (2001) put the duration of the larval stage between 120 and 200 degree days.

The juvenile stage has essentially been studied by means of experiments in the laboratory and only two references propose optimum temperatures: Karas (1990) found that growth ceases below temperatures of $8-10^{\circ} \mathrm{C}$ and Hokanson and Kleiner (1974) put the optimum at $25^{\circ} \mathrm{C}$. The synthesis of Hokanson (1977) quotes CT maximum values around $35.5^{\circ} \mathrm{C}$ (Weatherley, 1973) and $35.9^{\circ} \mathrm{C}$ (Horoszewicz, 1973) as well as IULT values between $31.4^{\circ} \mathrm{C}$ (Alabaster and Downing, 1966) and $33.5^{\circ} \mathrm{C}$ (Willemsen, 1977) for an acclimation temperature between $25^{\circ} \mathrm{C}$ and $30^{\circ} \mathrm{C}$. These IULT values appear more consistent with the optimum range chosen; the $32{ }^{\circ} \mathrm{C}$ value is therefore taken instead of $35^{\circ} \mathrm{C}$ to represent the upper boundary temperature tolerated by this stage.

For the adult, many authors have inventoried boundary temperatures. The optimum range appears to fall between $16{ }^{\circ} \mathrm{C}$ and $27^{\circ} \mathrm{C}$ (Horoszewicz, 1973 in Hokanson, 1977; Craig, 1978 in England). There is an extended range of optimum temperatures between $12^{\circ} \mathrm{C}$ and $31^{\circ} \mathrm{C}$ in North America and in Australia, where the species has been introduced (Thorpe, 1977b). Keith and Allardi (2001) report that growth ceases at around $10^{\circ} \mathrm{C}$. Finally, three authors give lethal temperatures in situ that are dependent on the acclimation temperature: Shkorbatov (1964 in Alabaster and Lloyd, 1982) found mortality at $30^{\circ} \mathrm{C}$ and $33.5^{\circ} \mathrm{C}$ in Russia; Filon (1972 in Alabaster and Lloyd, 1982), however, reports lethal temperatures of $23.2^{\circ} \mathrm{C}$ (for acclimation at $0.1^{\circ} \mathrm{C}$ ) and $36.2^{\circ} \mathrm{C}$ (for acclimation at $28.4^{\circ} \mathrm{C}$ ), also in Russia; these values are consistent with those found by Horoszewicz (1973 in Alabaster and Lloyd, 1982) in Poland. Boundary temperatures established in the laboratory (IULT and CT maximum) have been proposed by seven authors. Willemsen (1977 in Alabaster and Lloyd, 1982) and EIFAC (1969 in Küttel et al., 2002) give CT maxima of $33^{\circ} \mathrm{C}$ and $34^{\circ} \mathrm{C}$ respectively (taken as the upper boundary temperature tolerated by this life stage). Varley (1967 in Küttel et al., 2002), Colette et al. (1977) in Iran, Thorpe (1977b) and Müller (1997 in Küttel et al., 2002), recorded IULT values over an unspecified period of time that range between $30^{\circ} \mathrm{C}$ and $33.5^{\circ} \mathrm{C}$. Alabaster (1964) established IULT values of between $24^{\circ} \mathrm{C}$ and $31.4^{\circ} \mathrm{C}$ for 1000 minutes and for acclimation temperatures between $6{ }^{\circ} \mathrm{C}$ and $25^{\circ} \mathrm{C}$.

In his synthesis, Hokanson (1977) proposes a range of optimum temperatures for reproduction between $5^{\circ} \mathrm{C}$ and $19{ }^{\circ} \mathrm{C}$ depending on the region (EIFAC, 1968; Bastl, 1969; Kovalev, 1973), which is consistent with the broad range found in the literature (Thorpe, 1977a; Alabaster and Lloyd, 1982; Poncin, 1996 on the Meuse; Elliott, 1981 in Küttel et al., 2002). The limited range lies between $8{ }^{\circ} \mathrm{C}$ and $15^{\circ} \mathrm{C}$ (Lam, 1983; Gillet, 1989; Philippart et al., 1989; Mann, 1996; Gillet and Dubois, 2007 on Lake Geneva; Teletchea et al., 2009b; Fishbase).

\section{Ruffe (Gymnocephalus cernuus)}

The thermal optimum for the ruffe embryo has been recorded between $9{ }^{\circ} \mathrm{C}$ and $21^{\circ} \mathrm{C}$ in the laboratory (Saat and Veersalu, 1996) and the maxima tolerated are between $6{ }^{\circ} \mathrm{C}$ and $24^{\circ} \mathrm{C}$, also in the laboratory (Saat and Veersalu, 1996). The periods of incubation given by Ogle (1998), Bruslé and Quignard (2001) and Teletchea et al. (2009b) are consistent: 10 days at $12.5^{\circ} \mathrm{C}, 8$ days at $14.5^{\circ} \mathrm{C}$ and between 5 and 12 days at $10-15^{\circ} \mathrm{C}$ respectively. Fairchild and McCormick (1996), on the other hand, found much longer incubation periods for the ruffe: 9 , 14 and 26 days at $11^{\circ} \mathrm{C}, 16{ }^{\circ} \mathrm{C}$ and $21^{\circ} \mathrm{C}$ respectively.

The optimum range for larvae falls between $25^{\circ} \mathrm{C}$ and $30^{\circ} \mathrm{C}$ (Kammerer, 1907), and the minimum temperature tolerated is $10^{\circ} \mathrm{C}$ (Hokanson, 1977 in Ogle, 1998). 
Ruffe juveniles grow between $7^{\circ} \mathrm{C}$ and $24.8^{\circ} \mathrm{C}$, with an optimum at $21^{\circ} \mathrm{C}$ (Edsall et al., 1993 in Ogle, 1998). Hokanson (1977) reports two boundary temperatures recorded in the laboratory: one IULT for 1000 min of $30.4^{\circ} \mathrm{C}$ after acclimation for 11 days at $20^{\circ} \mathrm{C}$ (Alabaster and Downing, 1966) and a CT maximum of $34.5^{\circ} \mathrm{C}$ after acclimation at $24.1-25.7^{\circ} \mathrm{C}$ (Horoszewicz, 1973). The maximum temperature tolerated by the ruffe juvenile is taken as $30^{\circ} \mathrm{C}$, since the $\mathrm{CT}$ max was measured at an acclimation temperature at the extreme of the optimum range for this stage.

Alabaster (1964) conducted laboratory tests on adults at $15^{\circ} \mathrm{C}$ and $20^{\circ} \mathrm{C}$ : he found respective IULTs of $28.1^{\circ} \mathrm{C}$ and $30.4^{\circ} \mathrm{C}$ for $1000 \mathrm{~min}$. The optimum range retained here is between $15^{\circ} \mathrm{C}$ and $25{ }^{\circ} \mathrm{C}$ (the maximum optimum temperature retained for the juvenile), with a maximum of $31^{\circ} \mathrm{C}$ (Alabaster, 1964).

Reproduction occurs for ruffe between $6{ }^{\circ} \mathrm{C}$ and $18^{\circ} \mathrm{C}$ (Kolomin, 1977; Ogle, 1998; Keith and Allardi, 2001). The University of Minnesota website states that spermatogenesis occurs between $2{ }^{\circ} \mathrm{C}$ and $18^{\circ} \mathrm{C}$ (Butskaya, 1985).

\section{Pike-perch (Sander lucioperca)}

Many articles have reported on the thermal tolerances of the pike-perch embryo (Hokanson, 1977; Gillet, 1989; Lappalainen, 2001; Küttel et al., 2002; Lappalainen et al., 2003). The range of optimum temperatures for this stage falls between $12{ }^{\circ} \mathrm{C}$ and $20^{\circ} \mathrm{C}$ (Alabaster and Lloyd, 1982; Elliott, 1981 in Küttel et al., 2002; Muntyan, 1967 in Lappalainen et al., 2003; Kokurewicz, 1969 in Lappalainen et al., 2003). There is a more extended range whose lower boundary lies between $3{ }^{\circ} \mathrm{C}$ (Hassler, 1982 in Gillet, 1989) and $8{ }^{\circ} \mathrm{C}$ (Muntyan, 1967 in Lappalainen, 2001) with the upper boundary at $24^{\circ} \mathrm{C}$ (Elliott, 1981 in Küttel et al., 2002). Deelder and Willemsen (1964 in Hokanson,1977) and Muntyan (1967 in Hokanson, 1977) give ILLT and IULT values between $9{ }^{\circ} \mathrm{C}$ and $24^{\circ} \mathrm{C}$, which corresponds to this broad range of tolerated temperatures. Alabaster and Lloyd (1982) also report a CT minimum of $7^{\circ} \mathrm{C}$ and a CT max of $25^{\circ} \mathrm{C}$. This CT max was chosen as the upper boundary temperature tolerated by this stage. Gillet (1989) reported a period of 120 degree-days between egg-laying and hatching, consistent with the 8 days at $14.5^{\circ} \mathrm{C}$ quoted by Teletchea et al. (2009b).

The various authors who have studied the larval stage of the pike-perch propose optimum temperatures between $14{ }^{\circ} \mathrm{C}$ and $23^{\circ} \mathrm{C}$ (Hokanson, 1977; Teletchea et al., 2009b; Fishbase), and even $26{ }^{\circ} \mathrm{C}$ (Zhdanova, 1966 in Hokanson, 1977 in Russia and in Finland). There are also two boundary temperature values established in the laboratory for the larval stage: an IULT of $31^{\circ} \mathrm{C}$ and an ILLT of $6{ }^{\circ} \mathrm{C}$ (Hokanson, 1977).

Two authors have proposed a thermal profile for the juvenile stage (Horoszewicz, 1973 in Hokanson, 1977; Hokanson, 1977). The optimum temperature falls between $27.3^{\circ} \mathrm{C}$ and $30^{\circ} \mathrm{C}$ (Hokanson, 1977). The upper boundary temperatures determined in the laboratory are between $34.3^{\circ} \mathrm{C}$ (IULT for $1000 \mathrm{~min}$ ) and $37^{\circ} \mathrm{C}$ (CT maximum) for acclimation at $25.6{ }^{\circ} \mathrm{C}$ (Horoszewicz, 1973 in Hokanson, 1977). For the sake of consistency, the temperature retained as the upper boundary temperature is $34^{\circ} \mathrm{C}$.

For the adult stage, all available data has been provided by Alabaster and Lloyd (1982). Two field studies of mortality in Eastern Europe report lethal temperatures between $31.5^{\circ} \mathrm{C}$ and $37^{\circ} \mathrm{C}$ (Poltavchuk, 1965 in Russia; Horoszewicz, 1973 in Poland) for acclimation between $21^{\circ} \mathrm{C}$ and $25.6^{\circ} \mathrm{C}$, with maximum tolerated temperatures of $33.3^{\circ} \mathrm{C}$ in Poland (Horoszewicz, 1973). Lastly, Willemsen (1977) reports a CT maximum of $35.4^{\circ} \mathrm{C}$ in the Netherlands (acclimation at $25^{\circ} \mathrm{C}$ ), which has been retained as the upper boundary temperature. The range of optimum temperatures is taken as identical to that of the juveniles (optimum between $27^{\circ} \mathrm{C}$ and $30^{\circ} \mathrm{C}$ ).

The temperatures for the beginning and end of reproduction have been reported by seven authors, with boundary values of $3{ }^{\circ} \mathrm{C}$ in Eastern Europe and $26^{\circ} \mathrm{C}$ in Finland (Zhdanova, 1966; Alabaster and Lloyd, 1982; Raikova-Petrova and Divkov, 1998). All other references place the lower boundary temperature at around 6-8 ${ }^{\circ} \mathrm{C}$ (Fishbase; Hokanson, 1977; Deelder and Willemsen, 1964 in Gillet, 1989; Gillet, 1989; Mann, 1996; Raikova-Petrova and Divkov, 
1998 in Bulgaria; EIFAC, 1969 in Küttel et al., 2002; Fontell et al., 2004 in Finland; Teletchea et al., 2009b) and the upper boundary value at $20^{\circ} \mathrm{C}$ (Hokanson, 1977; Gillet, 1989; Mann, 1996; EIFAC, 1969 in Küttel et al., 2002; Fontell et al., 2004 in Finland).

\section{> ESOCIDAE FAMILY}

\section{Northern pike (Esox lucius)}

The optimum temperature for the northern pike embryo ranges between $8{ }^{\circ} \mathrm{C}$ and $14{ }^{\circ} \mathrm{C}$ (Willemsen, 1959), with extremes tolerated of $4^{\circ} \mathrm{C}$ and $23^{\circ} \mathrm{C}$ in the laboratory (Lindroth, 1946; Lillelund, 1966; Ignatieva and Kostomarova, 1966 in Saat and Versaluu, 1996). The minimum lethal temperature is $3^{\circ} \mathrm{C}$ (Hassler, 1982), while Steffens (1976) places the maximum lethal temperature at $21^{\circ} \mathrm{C}$ in Germany (a value lower than the extended optimum quoted). Hassler (1982) mentions tolerance on the part of northern pike embryos to diurnal temperature variations of $4{ }^{\circ} \mathrm{C}$ in the laboratory. The three data found in the literature referring to the duration of the embryo stage (Chimits, 1956; Braum, 1963; Teletchea et al., 2009b) follow the equation established by Lindroth (1946):

$$
D=4+1.2619-T
$$

$D$ : day of incubation and $T$ : water temperature in ${ }^{\circ} \mathrm{C}$, within the range of $10-14{ }^{\circ} \mathrm{C}$.

Hokanson et al. (1973 in Hokanson, 1977) recorded an IULT of $28.4^{\circ} \mathrm{C}$ for larva and estimate the maximum tolerated temperature at $28^{\circ} \mathrm{C}$. The optimum is more likely between $12{ }^{\circ} \mathrm{C}$ and $21^{\circ} \mathrm{C}$ (Hokanson et al., 1973; Teletchea et al., 2009b).

Casselman (1978 in Jobling, 1981) places the optimum temperature for growth of northern pike juveniles in Canada between $19^{\circ} \mathrm{C}$ and $21^{\circ} \mathrm{C}$. Cvancara et al. (1977) recorded an LD50 of $30.8^{\circ} \mathrm{C}$ and an IULT of $29.4^{\circ} \mathrm{C}$ in the Mississippi and Scott (1964 in Hokanson, 1977), an IULT of $33^{\circ} \mathrm{C}$ in the laboratory. The LD50 found, equivalent to a CT max, is taken to be the upper boundary temperature tolerated by the northern pike juvenile.

The optimum temperature for the adult stage ranges between $10^{\circ} \mathrm{C}$ and $24^{\circ} \mathrm{C}$ (Mc Cauley and Casselman, 1981; Keith and Allardi, 2001), according to three references (Hokanson, 1977 in Jobling, 1981; Casselman, 1978 in Canada, in Jobling, 1981; Craig, 1996 in Bruslé and Quignard, 2001). The upper boundary temperature was found to be $26^{\circ} \mathrm{C}$ in Ohio, USA (Bevelhimer et al., 1985) and an extended range of $4-27^{\circ} \mathrm{C}$ was observed on the Rhône (Ginot et al., 1996). The upper lethal temperature was found in the laboratory to be $34^{\circ} \mathrm{C}$ (Scott, 1964 in Jobling, 1981) while Casselman (1978) found a lower lethal temperature of $0.1^{\circ} \mathrm{C}$ in Ontario (Canada). Hokanson et al. (1973 in Hokanson, 1977) and Casselman (1978) give an IULT of around $29^{\circ} \mathrm{C}$, comparable to the lethal temperature given by Huet (1962) in the natural environment. For the sake of consistency, the authors have retained $31^{\circ} \mathrm{C}$ as the upper boundary, the same value as found for the preceding stage.

Lastly, reproduction occurs optimally between $8^{\circ} \mathrm{C}$ (Dubé and Gravel, 1978) and $15^{\circ} \mathrm{C}$ (Machniak, 1975), with three references to optimum temperatures in this same range (Bryan, 1967 in the USA; Dubé and Gravel, 1978 in Canada; Teletchea et al., 2009b). The extended range is between $6{ }^{\circ} \mathrm{C}$ (Machniak, 1975; Dumont et al., 1980 in Canada) and $20{ }^{\circ} \mathrm{C}$ (Machniak, 1975), with two authors quoting upper boundary temperatures found in the laboratory between $15^{\circ} \mathrm{C}$ and $20^{\circ} \mathrm{C}$ (Franklin and Smith, 1963; Hokanson et al., 1973 in Hokanson, 1977). Only two authors mention boundary temperatures below $4{ }^{\circ} \mathrm{C}$ (Machniak, 1975; Ovidio and Philippart, 2005 in Belgium).

\section{> CENTRARCHIDAE FAMILY}

\section{Pumpkinseed (Lepomis gibbosus)}

The duration of the embryo stage between egg-laying and hatching of the pumpkinseed larva is estimated at 3.1 days at $22.5^{\circ} \mathrm{C}$ (Teletchea et al., 2009b). 
The optimum for the larva is $20.4{ }^{\circ} \mathrm{C}$ according to Fishbase, while Teletchea et al. (2009b) place it higher $\left(23.5^{\circ} \mathrm{C}\right)$.

The optimum temperature for juveniles is between $13^{\circ} \mathrm{C}$ and $28^{\circ} \mathrm{C}$ in Greece (Neophitou and Giapis, 1994 in Küttel et al., 2002). An IULT of $30.2^{\circ} \mathrm{C}$ was established by Black (1953 in EPRI, 1981 ) in Canada. Ferguson (1958 in Coutant, 1977) found a higher optimum temperature in the laboratory $\left(31.5^{\circ} \mathrm{C}\right)$.

In the EPRI summary (1981) of studies conducted in the United States, the adult appears to tolerate temperatures between $11.9^{\circ} \mathrm{C}$ (Marcy, 1976) and $35^{\circ} \mathrm{C}$ (Trembley, 1960; Neill, 1974). The optimum for growth, according to Brett (1979), is $30^{\circ} \mathrm{C}$ and three data given by Coutant (1977) are below $28^{\circ} \mathrm{C}$ (Neill, 1974 in Coutant, 1977; Reutter and Herdendorf, 1974 in Coutant, 1977), which argues for an upper boundary for the optimum range around this temperature. Four references (Trembley, 1960; Neill, 1974; Marcy and Jacobson, 1976; Wapora, 1977) listed by EPRI (1981) give higher maximum temperatures, more consistent with those found in the laboratory. CT maximum values have been established experimentally: Beitinger and Bennet (2000) give values between $30.1^{\circ} \mathrm{C}$ and $35.1^{\circ} \mathrm{C}$ (Becker and Genoway, 1979) depending on the acclimation temperature $\left(10^{\circ} \mathrm{C}\right.$ and $20^{\circ} \mathrm{C}$ respectively) in the United States. Hagen's synthesis (1973) mentions comparable CT maxima $\left(25.5^{\circ} \mathrm{C}\right.$ to $\left.34.5^{\circ} \mathrm{C}\right)$ observed by Jones (1964). Burns (1973) and Reutter and Herdendorf (1976) report a slightly higher CT maximum $\left(37.5^{\circ} \mathrm{C}\right)$. A temperature of $35^{\circ} \mathrm{C}$ has been retained by the authors as the upper boundary of the extreme range tolerated by this life stage. CT minima of $1.7^{\circ} \mathrm{C}$ to $12.1^{\circ} \mathrm{C}$ have also been recorded for acclimation temperatures of $15^{\circ} \mathrm{C}$ to $30^{\circ} \mathrm{C}$ (Becker et al., 1977 in Beitinger et al., 2000).

Temperatures during the reproduction are less well documented than for the other species studied. The upper boundary is $25^{\circ} \mathrm{C}$ in Greece (Neophitou and Giapis, 1994 in Küttel et al., 2002). The lower boundary temperature for reproduction may be around $13^{\circ} \mathrm{C}$. Three authors mention optima between these two boundary temperatures (Bruslé and Quignard, 2001; Wiliamson et al., 1993 in Küttel et al., 2002; Teletchea et al., 2009b).

\section{> SILURIDAE FAMILY}

\section{Wels catfish (Silurus glanis)}

The period of incubation of the catfish embryo is between 2 and 3 days at $22-25^{\circ} \mathrm{C}$, or some 55 degree days (Lelek and Penáz, 1963; Bruslé and Quignard, 2001; Keith and Allardi, 2001; Teletchea et al., 2009b).

The optimum temperature for the larval stage has been experimentally established at $24.5^{\circ} \mathrm{C}$ (Teletchea et al., 2009b). The minimum lethal temperature in the laboratory is estimated at $13^{\circ} \mathrm{C}$ (Mihalik, 1982).

The range of optimum temperatures for the adult catfish falls between $12{ }^{\circ} \mathrm{C}$ and $28^{\circ} \mathrm{C}($ Berg, 1964; Abdullayev et al., 1978; Hilge, 1985), but it can tolerate a broader range of temperatures, from $3{ }^{\circ} \mathrm{C}$ to $30^{\circ} \mathrm{C}$ (Schlumberger et al., 2001). Extreme temperatures below $12{ }^{\circ} \mathrm{C}$ are confirmed by three authors (Mihalik, 1982; Omarov and Popova, 1985; David, 2006). The only measurements of IULT are found in Vallod's synthesis (1987). These IULTs are between $30.2^{\circ} \mathrm{C}$ for acclimation at $10^{\circ} \mathrm{C}$ (lethal temperature of $30.5^{\circ} \mathrm{C}$ ) and $33^{\circ} \mathrm{C}$ for acclimation at $20^{\circ} \mathrm{C}$ (lethal temperature of $34.4^{\circ} \mathrm{C}$ ) (Toth et al., 1982 in Vallod, 1987). The authors have chosen the intermediate temperature of $32^{\circ} \mathrm{C}$ as the maximum upper boundary for the extended range of temperatures tolerated.

Finally, reproduction occurs optimally between $20^{\circ} \mathrm{C}$ (Horvath, 1977; Bruslé and Quignard, 2001) and $25^{\circ} \mathrm{C}$ (Woynarovich and Horvath, 1981; Bruslé and Quignard, 2001), and two authors mention optima determined in the laboratory within this temperature range (Horvart and Lucowicz, 1982 in Vallod, 1987; Teletchea et al., 2009b). Lower tolerated temperatures have also been reported of at least $17^{\circ} \mathrm{C}$ (Mohr, 1957; Mihalik, 1982 in the laboratory; Lelek, 1987). 
Table III

Optimum temperature range and upper limit of the resistance temperature range for each species.

\begin{tabular}{|l|c|c|c|c|c|c|c|c|c|c|c|c|c|c|}
\hline & \multicolumn{3}{|c|}{ Embryo } & \multicolumn{3}{|c|}{ Larva } & \multicolumn{3}{c|}{ Juvenile } & \multicolumn{3}{c|}{ Adult } & \multicolumn{2}{c|}{ Spawning } \\
\hline & $\begin{array}{l}\text { Opt. } \\
\text { min }\end{array}$ & $\begin{array}{l}\text { Opt. } \\
\text { max }\end{array}$ & $\begin{array}{l}\text { Opt. } \\
\text { min }\end{array}$ & $\begin{array}{l}\text { Opt. } \\
\text { max }\end{array}$ & MAX & $\begin{array}{c}\text { Opt. } \\
\text { min }\end{array}$ & $\begin{array}{c}\text { Opt. } \\
\text { max }\end{array}$ & $\begin{array}{c}\text { MAX } \\
\text { Opt. } \\
\text { min }\end{array}$ & $\begin{array}{l}\text { Opt. } \\
\text { max }\end{array}$ & MAX & $\begin{array}{c}\text { Opt. } \\
\text { min }\end{array}$ & MAX \\
\hline Tel & & & & & & & 13 & 15 & & 10 & 18 & 27 & 12 & 15 \\
\hline Cht & & & & 14 & 18 & & & & & 16 & 25 & & 9 & $\mathbf{1 4}$ \\
\hline Gob & 16 & 20 & & & & & $\mathbf{7}$ & $\mathbf{2 7}$ & & 7 & 30 & 36 & 12 & 17 \\
\hline Lec & 16 & 24 & 30 & 14 & 25 & & $\mathbf{1 4}$ & $\mathbf{2 5}$ & 30 & 14 & 24 & 30 & 15 & 20 \\
\hline Lel & 7 & 15 & 25 & 16 & 25 & & $\mathbf{1 2}$ & $\mathbf{2 5}$ & & 10 & $\mathbf{2 5}$ & 32 & 7 & 12 \\
\hline Abb & & & & 19 & 24 & & $\mathbf{1 2}$ & $\mathbf{2 4}$ & & $\mathbf{1 2}$ & 24 & 27 & 14 & 21 \\
\hline Bar & 16 & 21 & & 15 & 19 & 24 & 13 & $\mathbf{2 4}$ & 32 & 10 & 24 & 32 & 13 & 20 \\
\hline Bit & & & & & & & & & & 12 & 30 & 37 & 15 & 21 \\
\hline Rut & 12 & 24 & 26 & & & & 7 & 21 & 30 & 12 & 25 & 31 & 10 & 18 \\
\hline Alb & 21 & 27 & 31 & & & & & & & 20 & 30 & 35 & 15 & 28 \\
\hline Abr & 12 & 23 & 28 & & & & 14 & $\mathbf{2 8}$ & 34 & 10 & 26 & 35 & 12 & 20 \\
\hline Bli & & & & & & & & & & 16 & 25 & & 15 & 25 \\
\hline Per & 12 & 18 & 21 & 12 & 25 & 34 & 10 & 25 & 32 & 16 & 27 & 33 & 8 & 15 \\
\hline Gym & 9 & 21 & 24 & 25 & 30 & & 7 & 25 & 30 & 15 & $\mathbf{2 5}$ & 31 & 6 & 18 \\
\hline San & 12 & 20 & 25 & 14 & 23 & 31 & 27 & 30 & 34 & $\mathbf{2 7}$ & $\mathbf{3 0}$ & 35 & 6 & 20 \\
\hline Eso & 8 & 14 & 23 & 12 & 21 & 28 & 19 & 21 & 31 & 10 & 24 & $\mathbf{3 1}$ & 8 & 15 \\
\hline Lep & & & & & & & 13 & 28 & 30 & 12 & 30 & 35 & $\mathbf{1 3}$ & 25 \\
\hline Sil & & & & & & & & & & 12 & 28 & 32 & 20 & 25 \\
\hline
\end{tabular}

Italic and bold: data without associated reference (issued from precedent stage or estimated).

Opt. min and max: optimal range limits.

MAX: upper limit of the resistance range.

\section{> SYNTHESIS OF RANGES OF TOLERANCE}

The ranges of optimum temperatures together with the upper boundary of the range of resistance chosen for each stage of the species studied are found in Table III. All references on which our choices are based are listed in Appendix.

\section{DISCUSSION}

We have summarized the thermal tolerances of the target species on the basis of data with great geographical and temporal differences, obtained under diverse conditions, coming both from field observations and from controlled experiments in the laboratory. We provided a 
detailed table listing all references used (Appendix). Above all, we reserve the possibility of reevaluating the interpretation of the values we propose.

Wherever possible, we have given priority to the use of source data. We also collected data from existing compilations (Hokanson, 1977; Alabaster and Lloyd, 1982; Mann, 1996; Küttel et al., 2002; Teletchea et al., 2009b).

In the case of observations in the field, different temperatures tolerated within a single species or by a given life stage may be found. This may be attributable to geographical differences in thermal regime (Kottelat and Freyhof, 2007, for example, say that the ruffe begins to reproduce at $6{ }^{\circ} \mathrm{C}$ in northern Europe and only above $10^{\circ} \mathrm{C}$ in the south) or by the plasticity of the species. We know that there exists a natural phenotypic variation in thermal tolerance (Schaefer and Ryan, 2006), but the amplitude of variability and the point in ontogenesis at which it occurs are as yet poorly understood (Grünbaum et al., 2007). The zebrafish (Danio rerio), for example, a thermophilic fish with a short life cycle, has an intrinsic plasticity with greater tolerance on the part of adults to high temperatures when the juveniles also have been exposed to high temperatures (Schaefer and Ryan, 2006). Another reference for muskellunge (Esox masquinongy), however, shows no difference in thermal tolerance among 2-year-old individuals from different populations (Wagner et al., 2007). It is therefore a property difficult to generalize; we can note, however, that the truly reliable temperatures in situ are systematically around $1{ }^{\circ} \mathrm{C}$ to $4{ }^{\circ} \mathrm{C}$ lower than the lethal temperatures (Magnuson et al., 1979; Eaton et al., 1995); for this reason, we advise retaining as the benchmark the thermal tolerance maximum (7th column in the table in Appendix).

In addition to these considerations relating to variations among individuals or populations, further knowledge is needed for a good interpretation of thermal tolerance values:

- fish are extremely sensitive to temperatures in their environment; they can detect very minimal temperature changes on the order of $0.03^{\circ} \mathrm{C}$ (Bull, 1936);

- they have a tendency to select thermal habitats which maximize their growth rate (Magnuson et al., 1979);

- the lethal temperature may rise following progressive periods of acclimation, within a limit of $3{ }^{\circ} \mathrm{C}$ maximum for salmonids (e.g. Atlantic salmon, Garcia de Leaniz et al., 2007). But we must remember that the periods of acclimation are long, on the order of 20 days for ectotherms (Lutterschmidt and Hutchison, 1998);

- at the highest tolerated temperatures, we must allow for the potential risks of a diminished food supply and heightened sensitivity to toxicity related to xenobiotics (Heugens et al., 2001);

- adult fish subject to significant daily thermal amplitudes within their zone of maximum tolerated temperatures consume additional energy which is drawn from their growth functions or the production of gametes (Schaefer and Ryan, 2006: zebrafish subject to a thermal regime of $28 \pm 6{ }^{\circ} \mathrm{C}$ );

- in the larval stage, fish are more vulnerable to thermal stress, because they are less capable than adults of regulating membrane fluidity as well as of metabolic acclimation or behavioral thermoregulation (Brett, 1970; Rombough, 1997);

- on a daily scale, we must consider not only the maximum temperature tolerated but also its duration, and the temperature of nocturnal remission and its duration, which must be sufficient for the organism to repair its stress proteins. On a scale of several days, we must not underestimate the influence of cumulative exposure to temperatures close to the maximum tolerated temperatures;

- on a local scale (a few meters to a few hundred meters), there are temperature contrasts in streams and fish are able to seek out thermal refuges in tributaries, secondary channel, or cooler groundwater upwelling (Torgersen et al., 2001). Salmonids use these contrasts very effectively (Torgersen et al., 1999); the behavior of other families is less well documented; a radiotracking study conducted by Cooke et al. (2004) on small-mouth black bass (Micropterus dolomieu) showed that this species actively avoids the warmest 
zones around industrial releases and that once having "experienced" them, they never return.

Temperature $\left({ }^{\circ} \mathrm{C}\right)$

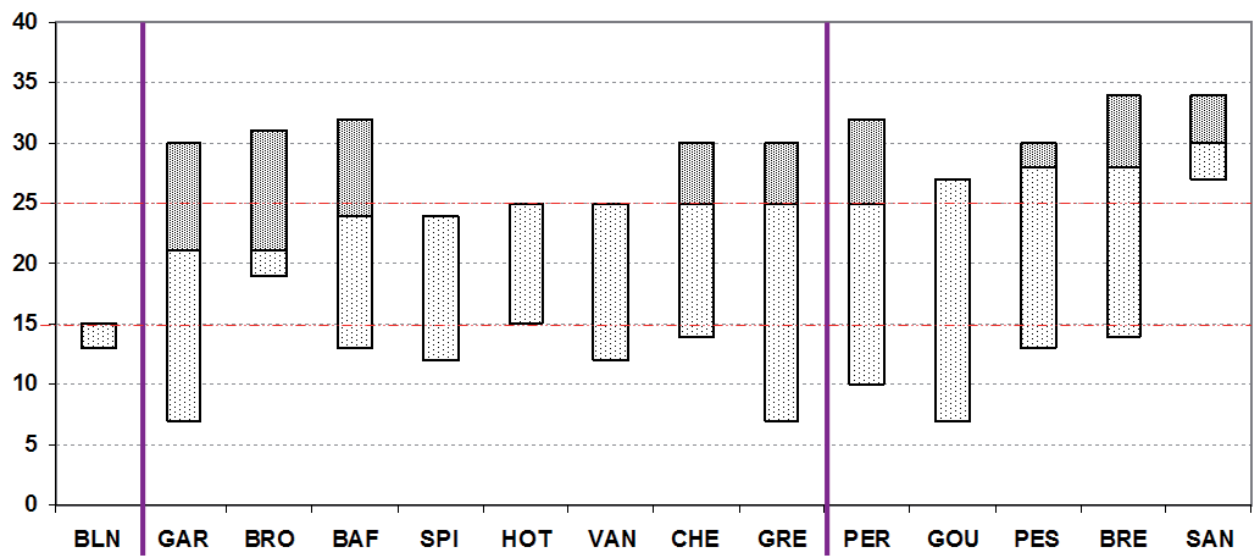

\section{Figure 2}

Optimum temperature range (light grey) and resistance temperature (dark grey) range for juvenile of each studied species. $\mathrm{N}$ species $=14$.

\section{Temperature $\left({ }^{\circ} \mathrm{C}\right)$}

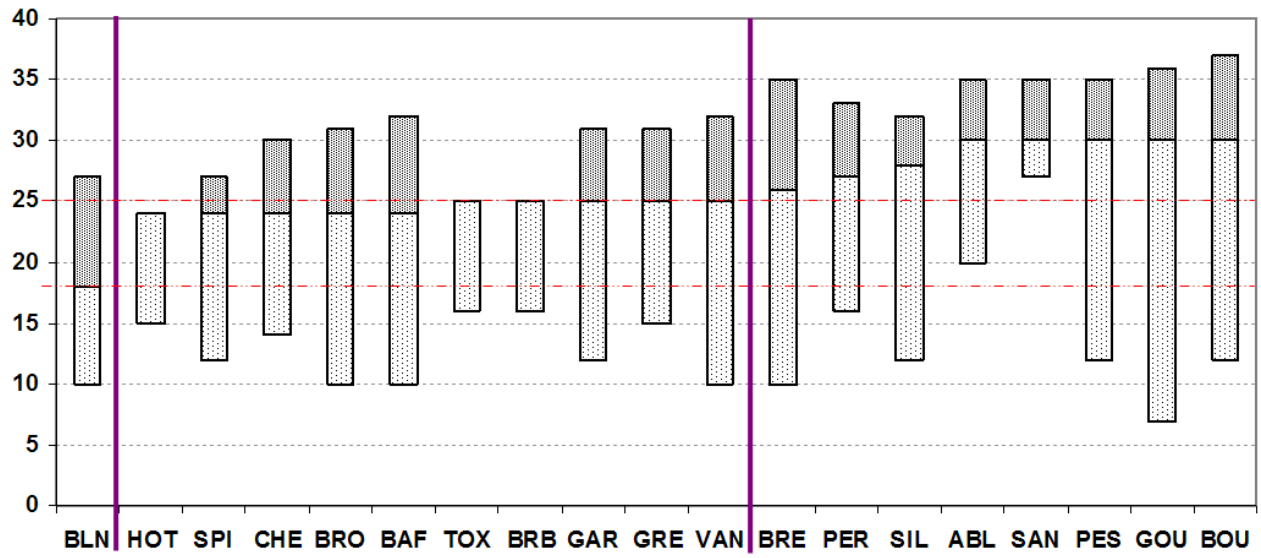

\section{Figure 3}

Optimum temperature range (light grey) and of the resistance temperature (dark grey) range for adult of each studied species. $\mathrm{N}$ species $=19$.

The range of optimum temperatures and the range of resistance we have retained (Table III) are shown in Figure 2 for juveniles and Figure 3 for adults. Generally speaking, the juvenile stage is far less well documented than the adult stage. The data is similarly not exhaustive on the upper boundary of the range of resistance.

These figures allow us to distinguish three groups of species, according to their thermal requirements:

- The vairone shows behavior that is quite distinct from the other species, with growth at a low temperature (a maximum optimum of $15^{\circ} \mathrm{C}$ for the juvenile and $18{ }^{\circ} \mathrm{C}$ for the adult). It is at the extreme end of the list of stenothermic coldwater fish; this is consistent with the position of these species in Verneaux's theoretical zonation (1981);

- One group we might call mesothermic includes the French nase, spirlin, chub, northern pike, barbel, sofie, white bream, roach, ruffe and dace, which grow at temperate 
temperatures: a maximum optimum around $20-25^{\circ} \mathrm{C}$ for juveniles and $25^{\circ} \mathrm{C}$ for adults; maximum tolerated slightly above $30^{\circ} \mathrm{C}$;

Temperature $\left({ }^{\circ} \mathrm{C}\right)$

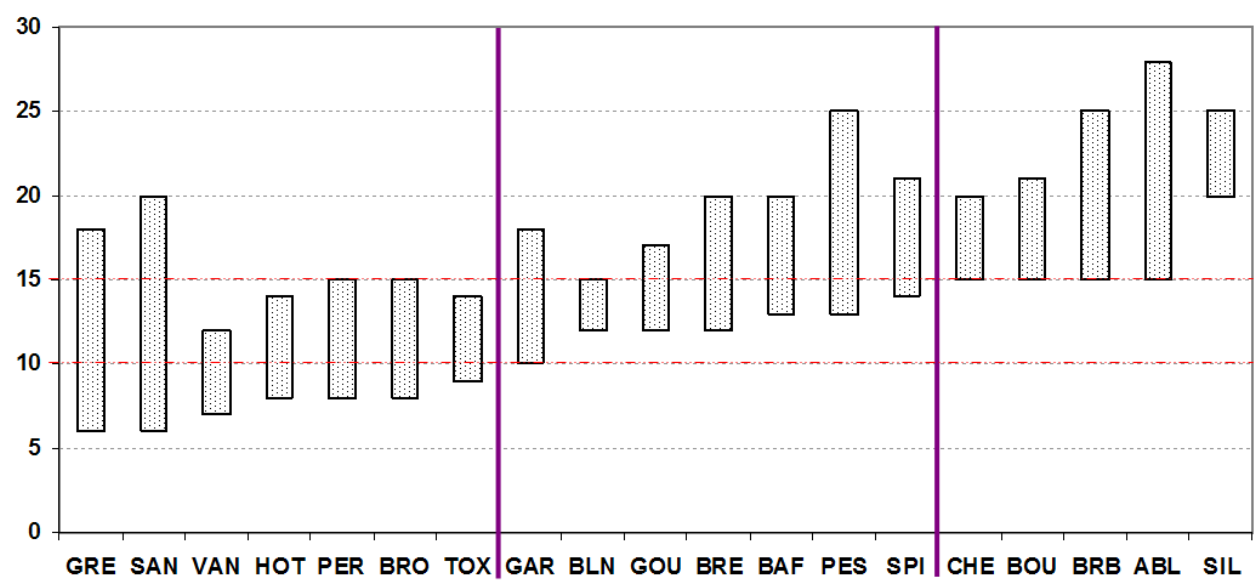

Figure 4

Optimal range of temperature for reproduction of each studied species.

- A third group far more tolerant of warm temperatures, consisting in the common bream, perch, catfish, bleak, pike-perch, pumpkinseed, gudgeon, and bitterling. The optimum temperature for adults can go up to $25-30{ }^{\circ} \mathrm{C}$ and the maxima tolerated may reach $37^{\circ} \mathrm{C}$ (it is always over $32{ }^{\circ} \mathrm{C}$ for adults).

Figure 4 gives the temperature optima for reproduction in these species.

According to the optimum range for reproduction, the 19 species again break down into three groups:

- One group for which reproduction may take place below $10{ }^{\circ} \mathrm{C}$ : ruffe, pike-perch, dace, nase, perch, northern pike and sofie;

- An intermediate group that can reproduce between $10^{\circ} \mathrm{C}$ and $15^{\circ} \mathrm{C}$ : roach, vairone, gudgeon, common bream, barbel, pumpkinseed and spirlin;

- One group that reproduces at temperatures higher than $15^{\circ} \mathrm{C}$ : chub, bitterling, white bream, bleak and catfish.

Depending on present and future thermal regimes, particularly in spring, which are reaching temperatures favorable to reproduction earlier and earlier (GIEC, 2007), some species will resist all the better because the amplitude of their thermal tolerance for reproduction is wide. These include the ruffe and pike-perch which have a broad thermal tolerance, unlike the dace, sofie and vairone. In addition, the species which show the greatest amplitude of tolerance for reproduction are often in the most tolerant group in the juvenile and adult stages and frequently, even, have a strategy of multiple spawning. These species will most likely develop better in hot years, as has been observed on the Rhône River at Bugey, France (Daufresne and Boët, 2007).

All typologies are at least partially arbitrary and our own is no exception. We have tried to report on data relating to the 19 species studied, identifying three thresholds for the metrics of maximum thermal optimum for the adult, $18^{\circ} \mathrm{C}, 25^{\circ} \mathrm{C}$ and $30^{\circ} \mathrm{C}$; because we did not include salmonids and other species in the apical zone in streams, it is not surprising to find only the vairone in the first group of coldwater stenothermic fish, for which Raat (1988) places the upper boundary at $19^{\circ} \mathrm{C}$ and the optimum at $15^{\circ} \mathrm{C}$, while Hokanson (1977) sets it at $20^{\circ} \mathrm{C}$. We quite clearly distinguish a group of mesothermic fish, within which most rheophilic cyprinids are found, and a group more tolerant to warmer temperatures that includes 
essentially more lenitophilic cyprinids. We suggest some nuances in relation to Raat (1988), whose boundary values for these same groups were closer, respectively $\left(19-21^{\circ} \mathrm{C}\right.$, optimum for growth $19{ }^{\circ} \mathrm{C}$, and $>21^{\circ} \mathrm{C}$, optimum for growth, $\left.27^{\circ} \mathrm{C}\right)$ or Hokanson $(1977)\left(<28^{\circ} \mathrm{C}\right.$ and $>28^{\circ} \mathrm{C}$ ). With respect to certain species, we differ from Daufresne and Boët (2007) in classifying the white bream (mesothermic group in our synthesis, rather than warmwater group), pumpkinseed and perch (warmwater as opposed to coldwater group in this synthesis).

The thermal tolerance groupings we find already provide indicative values which may be valuable in situating the probabilities of modifications in the fish communities within given thermal ranges. It nonetheless remains indispensable to look both at thermal regime (temperature intensity, duration, frequency and seasonality and rate of changes) and the different life stages of the species.

We recommend, on the one hand, giving priority to species-specific data for any analysis of past trends and, on the other, being careful to analyze coupled regimes, i.e. biology (different life stages) and temperature. This will be all the more important for any attempt to make trend forecasts corresponding to scenarios of global change, in which it will be necessary to allow not only for seasonal temperature changes but also for a modified hydrological regime (Graham and Harrod, 2009).

\section{CONCLUSION AND PROSPECTS}

Temperature is one of the key variables in the dynamics of a hydrosystem: it is subject to local changes downstream of urbanized or industrial sites or rural areas in which wooded riparian corridors capable of acting as a thermal buffer have been significantly reduced. More global changes of a climatic origin have also been recorded in recent decades and may continue into the future according to various scenarios of climate change. Ecologists are therefore naturally forced to investigate the sensitivity of the environment to these changes and the tolerance of aquatic species. With this synthesis, we provide elements of knowledge which until now have been disparate and sometimes, in the case of early literature, difficult to access. In diagnoses or prognoses of sensitivity to thermal changes, it is important that we be able to share information based on a common set of knowledge. This synthesis enables identifying the species capable of withstanding a rise in temperature better than others. Above and beyond these results, it is still important to remember that other factors impact the ability of species to withstand rising temperatures.

This synthesis also points up the knowledge that is lacking for certain life stages or certain species (in particular, the vairone, sofie, bitterling and white bream); this may help direct further investigations in the future, whether of an ecological nature, through field studies coupling temperatures and the presence of fish, or more physiological in the laboratory, on boundary thermal tolerances.

These results could also be extremely valuable to improve our understanding of the present geographical distribution of fish and our ability to interpret changes in the communities over time on sites with sufficiently documented time series data.

\section{ACKNOWLEDGMENTS}

This paper has been previously published in a French version in Hydroécologie Appliquée (2010) Tome 17, 17-76.

We have turned to European experts in the scientific field to complete and validate the synthesis drawn up here. The authors wish to thank the following for contributing to this synthesis and for the references they have shared: Christian Gillet (INRA, France: northern pike, river perch and roach), Rodolphe Gozlan (University of Bournemouth, England: sofie), Michel Khalanski (EDF Hydroecology Committee), Krzysztof Kupren (University of Warminsko-Mazurski, Poland: dace and chub), Alain Nelva (University of Savoie, France: 
French nase), Nicolas Poulet (Onema, France: pike-perch) and Dominique Vallod (ISARA, France: catfish). For general assistance and bibliographical recommendations, the authors also thank: Jérôme Belliard (Irstea, France), Georges Carrel (Irstea, France), Cordon Copp (University of Bournemouth, England), Pascal Fontaine and Fabrice Teletchea (University of Lorraine, France) and Martin Reichard (Academy of Sciences, the Czech Republic).

We also acknowledge two anonymous referees for their careful and very useful review of the paper. Sorry for the frustration due to the lack of Thymallus thymallus in our review. And finally, deep thanks go to Federica Oraison for invaluable assistance in our documentary research and for a first reading of the text and to Lucy Laederich for English translation of numerous boring paragraphs, especially when fish is not her passion...

\section{REFERENCES}

Abdullayev M.A., Khakberdiev B. and Urchinov D., 1978. Biology of the catfish Silurus glanis from some lakes in the lower Zarafshan River and in the Khorezm district. J. Ichtyol., 17, 487-491.

Alabaster J.S., 1964. The effect of heated effluents on fish. In: International conference on water pollution research, N.Y. Pergamon Press Ed., 261-292.

Alabaster J.S. and Downing A.L., 1966. A field and laboratory investigation of the effect of heated effluents on fish, Min. Agric. Fish. Food (Gt. Brit.) Ser. I, 1-42.

Alabaster J.S. and Lloyd R., 1982. Water temperature. In: Alabaster J.S. and Lloyd R. (eds.), Water quality criteria for freshwater fish, 47-102.

Allan J.D., 1995. Stream ecology: structure and function of running waters, Chapman \& Hall, London, $388 \mathrm{p}$.

Armour C., 1991. Guidance for evaluating and recommending temperature regimes to protect fish, U. S. Wildlife Service, Washington, 13.

Balon E.K., 1975. Terminology of Intervals in Fish Development. Journal de l'Office des Recherches sur les Pêcheries du Canada, 32, 1663-1670.

Banarescu P., 1964. Fauna republicii populare Romine, Pisce-Osteichthyes, Bucuresti, $962 \mathrm{p}$.

Banarescu P.M., Bogutskaya N.G., Movchan Y.V. and Smirnov A.I., 2003a. Barbus barbus (Linnaeus, 1758). In: Banarescu P. and Bogutskaya N.G. (eds.), The freshwater fishes of Europe, 43-90.

Banarescu P.M., Soric V.M. and Economidis P.S., 2003b. Gobio gobio (Linnaeus, 1758). In: Banarescu P. and Bogutskaya N.G. (eds.), The freshwater fishes of Europe, 81-126.

Baras E., 1995. Thermal related variations of seasonal and daily spawning periodicity in Barbus barbus. J. Fish Biol., 46, 915-917.

Baras E. and Philippart J.C., 1999. Adaptive and evolutionary significance of a reproductive thermal threshold in Barbus barbus. J. Fish Biol., 55, 354-375.

Barbier B. and Pascal M., 1976. Résistance du gardon (Rutilus rutilus L.) à des variations brusques de température. Cahiers du Laboratoire d'Hydrobiologie de Montereau, 3, 25-34.

Bartholow J., 2000. Estimating cumulative effects of clearcutting on stream temperatures. Rivers, 7, 284-297.

Barus V. and Prokes M., 1993. Fecundity of the bleak (Alburnus alburnus) in the Vestonice reservoir. Folia Zool., 42, 281-288.

Bastl I., 1969. Spawning of pike-perch (Stizostedion lucioperca Linneaeus, 1758) in bottom nests in conditions of the Orava Reservoir (Northern Slovakia). Pr. Laboratoria Rybarstva a Hydrobiol., 159-184.

Becker C.D. and Genoway R.G., 1979. Evaluation of the critical thermal maximum for determining thermal tolerance of freshwater fish. Environ. Biol. Fish., 4, 245-256.

Becker C.D., Genoway R.G. and Schneider M.J., 1977. Comparative cold resistance of three Columbia river organisms. Trans. Amer. Fish. Soc., 106, 178-184.

Beitinger T.L. and Bennett W.A., 2000. Quantification of the role of acclimation temperature in temperature tolerance of fishes. Environ. Biol. Fish., 58, 277-288.

Beitinger T.L., Bennett W.A. and McCauley R.W., 2000. Temperature tolerances of North American freshwater fishes exposed to dynamic changes in temperature. Environ. Biol. Fish., 58, 237-275.

Berg N., 1949. Ryby presnykh vod SSSR i sopredelnykh stran (Freshawater fishes of the USSR and of adjacent regions), Izdat. AN SSSR, Moska, Leningrad, 925 p.

Berg N., 1964. Freshwater fishes of the U.S.S.R. and adjacent countries, 470-474. 
Bernet B., 1960. Recherches biologiques sur les populations de Gobio gobio (Linné 1758) de la Nivelle (fleuve côtier du Pays Basque). Annales de la Station Centrale d'Hydrobiologie Appliquée, 8, 127-180.

Bevelhimer, Stein R.A. and Carline R.F., 1985. Assessing significance of physiological differences among three esocids with a bioenergetics model. Can. J. Fish. Aquat. Sci., 42, 57-69.

Black E.C., 1953. Upper lethal temperatures of some British Columbia freshwater fishes. J. Fish. Res. Board Can., 10, 196-210.

Bless R., 1996. Reproduction and habitat preference of the threatened spirlin (Alburnoides bipunctatus Bloch) and soufie (Leuciscus souffia Risso) under laboratory conditions (Teleostei: Cyprinidae). In: Kirchhofer A. and Hefti D. (eds.), Conservation of endangered freshwater fish in Europe, 249-258.

Bliss C.I., 1937. The calculation of time-mortality curve. Ann. Appl. Biol., 24, 815-852.

Bodareu M.N. and Karlov V.N., 1984. The barbel in the Dniester Basin, Schtiintsa, Kishiniov, 139 p.

Bohl E., Herrmann M., Ott B., Seitz B. and Heise J., 2004. Untersuchungen zur Fortpflanzungsbiologie, Entwicklung und zu den Lebensräumen von Schneider (Alburnoides bipunctatus BLOCH 1782) und Strömer (Leuciscus souffia agassizi VALENCIENNES 1844) - Abschlussbericht über die Untersuchungen 2002-2004, Bayerisches Landesamt für Wasserwirtschaft, Abteilung Gewässerökologische Forschung, Referat Fischökologie, 96.

Bourgeois M., 1963. La vandoise. La Pêche et les Poissons, 219, 39.

Bourgeois M., 1964. Le goujon. La Pêche et les Poissons, 229, 45.

Braum E., 1963. Die ersten Beutefanghandlungen junger Blaufelchen (Coregonus wartmanni Bloch) und Hechte (Esox lucius L.). Z. Tierpsychologie, 20, 257-266.

Breitenstein M. and Kirchhofer A., 1999. Biologie, menaces et protection du spirlin (Alburnoides bipunctatus) en Suisse, Office fédéral de l'environnement, des forêts et du paysage, $46 \mathrm{p}$.

Brett J.R., 1970. Environmental factors, Part I, Temperature. In: Kline O. (ed.), Marine Ecology, 515-560.

Brett J.R., 1979. Environmental factors and growth. In: Hoar W.S., Randall D.J. and Brett J.R. (eds.), Fish Physiology, 8, 599-675.

Brett J.R. and Higgs E., 1970. Effect of temperature on the rate of gastric digestion in fingerling sockeye salmon, Oncorhynchus nerka. J. Fish. Res. Board Can., 27, 1767-1779.

Brown J.H., Gillooly J.F., Allen A.P., Savage V.M. and West G.B., 2004. Toward a metabolic theory of ecology. Ecology, 85, 1771-1789.

Brunet R. and Hoestlandt H., 1972. Recherches biologiques et pisciculture expérimentale du goujon (Gobio gobio L.). Bull. Fr. Pêche Piscic., 246, 5-32.

Bruslé J. and Quignard J.P., 2001. Biologie des poissons d'eau douce européens, Lavoisier, Paris, 625 p.

Bryan J.E., 1967. Northern pike production in Phalen Pond, Minnesota. J. Minn. Acad. Sci. , 34, 101-109.

Brylinska M. and Zbikowska L., 1997. Ecology, growth and fecundity of a reproducing population of silver bream, Blicca bjoerkna, from a lowland river reservoir. Folia Zool., 46, 353-366.

Bull, H.O., 1936. Studies on conditioned responses in fishes. Part VII. Temperature perception of Teleots. J. Mar. Biol. Assoc. U.K., 21, 1-27.

Burns J.R., 1973. Seasonal changes in an environmental control of gonadal development, respiration, and temperature tolerance limits of the pumpkinseed, Lepomis gibbosus (pisces: centrarchidae), University of Massachusetts.

Burton T.M. and Likens G.E., 1973. Effect of strip-cutting on stream temperatures in Hubbard Brook experimental forest, new Hampshire. BioScience, 23, 433-435.

Butskaya N.A., 1985. Analysis of the productivity of spermatogenesis in different periods of the sexual cycle of ruffe, Gymnocephalus cernuus. J. Ichthyol., 25, 44-51.

Casselman J.M., 1978. Effects of environmental factors on growth, survival, activity, and exploitation of Northern Pike. Am. Fish. Soc. Spec. Publ., 11, 114-128.

Chappaz R., Brun G. and Olivari G., 1987. Mise en évidence de différences de régime alimentaire dans une population d'ablettes Alburnus alburnus L. dans le lac de Sainte-Croix. Conséquences sur la croissance et la fécondité. Ann. Limnol., 23, 245-252.

Chappaz R., Brun G. and Olivari G., 1989. Données nouvelles sur la biologie et l'écologie d'un poisson Cyprinidé peu étudié Chondrostoma toxostoma (Vallot, 1936). Comparaison avec Chondrostoma nasus (L., 1766). C.R. Acad. Sci. Paris, 309, 181-186.

Chimits P., 1956. Le brochet. Bull. Fr. Pêche Piscic., 180, 81-96.

Cocking A.W., 1959. The effects of high temperatures on roach (Rutilus rutilus) - I. The effects of constant high temperatures. J. Exp. Biol., 36, 203-216.

Collette B.B., Ali M.A., Hokanson K.E.F., Nagiec M., Smirnov S.A., Thorpe J.E., Weatherley A.H. and Willemsen J., 1977. Biology of the percids. J. Fish. Res. Board Can., 34, 1890-1899. 
Cooke S.J., Bunt C.M. and Schreer J.F., 2004. Understanding fish behavior, distribution, and survival in thermal effluents using fixed telemetry arrays: a case study of smallmouth bass in a discharge canal during winter. Environ. Manage., 33, 140-150.

Coutant C.C., 1975. Temperature selection by fish - A factor in power plant impact assessments. In: Environmental Effects of Cooling Systems at Nuclear Power Plants, 25 p.

Coutant C.C., 1977. Compilation of temperature preference data. J. Fish. Res. Board Can., 34, 739-745.

Cowles R.B. and Bogert C.M., 1944. A preliminary study of the thermal requirements of desert reptiles. Bull. Amer. Mus. Nat. Hist., 83, 265-296.

Cowx I.G. and Welcomme R.L., 1998. Rehabilitation of rivers for fish; A study undertaken by the European Inland Fisheries Advisory Commission of FAO, 260.

Craig J.F., 1978. A study of the food and feeding of perch, Perca fluviatilis L., in Windermere. Freshw. Biol., 8, 59-68.

Craig J., 1996. Pike: biology and exploitation, Chapman \& Hall, 320 p.

Cvancara A., Stieber S.F. and Cvancara B.A., 1977. Summer temperature tolerance of selected species of Mississippi River acclimated young of the year fishes. Comp. Biochem. Physiol., 56, 81-85.

Daufresne M. and Boët P., 2007. Climate change impacts on structure and diversity of fish communities in rivers. Glob. Chang. Biol., 13, 1-12.

Daufresne M., Lengfellner K. and Sommer U., 2009. Global warming benefits the small in aquatic ecosystems. Proc. Natl. Acad. Sci. USA, 106, 12788-12793.

Davey A.J.H., Kelly D.J. and Biggs B.J.F., 2006. Refuge-use strategies of stream fishes in response to extreme low flows. J. Fish Biol., 69, 1047-1059.

David J.A., 2006. Water quality and accelerated winter growth of European catfish using an enclosed recirculating system. Water Environ. J., 20, 233-239.

De Bono A., Peduzzi P., Kluser S. and Giuliani G., 2004. Impacts of summer 2003, United Nations Environment Programme, $4 \mathrm{p}$.

De Vlaming V.L., 1972. Environmental control of teleost reproductive cycles: a brief review. J. Fish Biol., 4, 131-140.

Deelder C.L. and Willemsen J., 1964. Synopsis of biological data on pike-perch Lucioperca lucioperca (Linnaeus, 1758), FAO Fisheries Synopsis, 57.

Diamond M., 1985. Some observations of spawning by roach, Rutilus rutilus L., and bream, Abramis brama L., and their implications for management. Aquacult. Fish. Manag., 16, 359-367.

Dubé J. and Gravel Y., 1978. Plan pilote d'aménagement intégré des ressources biologiques du territoire de la frayère du ruisseau Saint Jean, comté de Châteauguay, Québec, Montréal, 52 p.

Dumont P., Fortin R. and Fournier H., 1980. Certain aspects of the reproduction of upper Richelieu and Mississipi Bay northern pike, Esox lucius L., 231-248.

Duyvené de Wit J.J., 1955. Some observations on the European bitterling (Rhodeus amarus). S. Afr. J. Wetenskap, 51, 249-251.

Easton K.W. and Dolben I.P., 1980. The induced spawning and subsequent survival and growth of roach Rutilus rutilus (L.). Aquac. Res., 11, 59-66.

Eaton J.G., Mccormick J.H., Stefan H.G. and Hondzo M., 1995. Extreme value analysis of a fish/temperature field database. Ecol. Eng., 4, 289-305.

Edsall T.A., Selgeby J.H., DeSorcie T.J. and III J.R.P.F., 1993. Growth-temperature relation for youngof-the-year ruffe. J. Great. Lakes Res., 19, 630-633.

EIFAC, 1968. Water quality criteria for european freshwater fish, Report on water temperature and inland fisheries based mainly on Slavonic literature, 6-32.

EIFAC, 1969. Water quality criteria for European freshwater fish, Water temperature and inland fisheries. Water Res., 3, 645-662.

Elliott J.M., 1981. Some aspects of thermal stress on freshwater teleosts. In: Pickering A.D. (ed.), Stress and fish, 209-245.

Elliott J.M., 1994. Quantitative ecology and the brown trout, Oxford University Press, Oxford GBR, 286 p.

EPRI, 1981. Literature review: response of fish to thermal discharges, Electric Power Research Institue.

Fairchild D.J. and McCormick J.H., 1996. Effects of temperature on hatching and development of ruffe (Gymnocephalus cernuus). J. Geart. Lakes Res., 22, 89-94.

Ferguson R.G., 1958. The preferred temperature of fish and their midsummer distribution in temperate lakes and streams. J. Fish. Res. Board Can., 15, 607-624.

Filipi N., 1962. Kontribut mbi njohjen e morfologjise e biologjise skobusit te lumit (Chondrostoma nasus ohridanus) ne liqenin e Pogradecit [Contribution à la connaissance de la morphologie et de la 
biologie du Chondrostome du fleuve (Ch. nasus ohridanus) dans le lac de Pogradec], Bill. Puni. Ekon. Peshk. Albane, 1, 146-168.

Filon V.V., 1972. Increase in the temperature at which roach, perch and rudd survive in warm waters from the Knonakovo hydroelectric power station, Hydrobiol. J., 7, 69-72.

Fontell E., Lehtonen H. and Lappalainen J., 2004. Influence of temperature and depth on spawning site selection of pikeperch (Sander lucioperca) in the Helsinki sea area. In: T.P.B.a.J.A.M. (eds.), Proceedings of Percis III. The Third International Percid Fish Symposium, 103-104.

Franklin D.R. and Smith L.L., 1963. Early life history of the northern pike, Esox lucius L., with special reference to the factors influencing the numerical strength of year classes. Trans. Amer. Fish. Soc., 92, 91-110.

Fry F.E.J., 1971. The effects of environmental factors on physiology of fish. In: Fish Physiology, 1-98.

Fry F.E.J., Brett J.R. and Clawson G.H., 1942. Lethal limits of temperature for young goldfish. Rev. Can. Biol., 1, 50-56.

Garcia de Leaniz C., Fleming I.A., Einum S., Verspoor E., Jordan W.C., Consuegra S., Aubin-Horth N., Lajus D., Letcher B.H., Youngson A.F., Webb J.H., Vollestad L.A., Villanueva B., Ferguson A. and Quinn T.P., 2007. A critical review of adaptive genetic variation in Atlantic salmon: Implications for conservation. Biol. Rev., 82, 173-211.

GIEC, 2007. Résumé à l'intention des décideurs, Cambridge University Press, Cambridge, UK and New York, USA, 18.

Gillet C., 1989. Le déroulement de la fraie des principaux poissons lacustres. Hydroecol. Appl., 1, 117-143.

Gillet C. and Dubois J.P., 2007. Effect of water temperature and size of females on the timing of spawning of perch Perca fluviatilis L. in Lake Geneva from 1984 to 2003. J. Fish Biol., 70, 1001-1014.

Gillet C. and Quétin P., 2006. Effect of temperature changes on the reproductive cycle of roach in Lake Geneva from 1983 to 2001. J. Fish Biol., 69, 518-534.

Gillooly J.F., Brown J.H., West G.B., Savage V.M. and Charnov E.L., 2001. Effects of size and temperature on metabolic rate. Science, 293, 2248-2251.

Ginot V., Souchon Y. and Roger P., 1996. Impact de l'élévation artificielle de température induite par le fonctionnement du Centre Nucléaire de Production Electrique du Bugey (fleuve Rhône) sur les communautés de poissons. Hydroecol. Appl., 8, 1-33.

Gozlan R.E., 1998. Environmental biology and morphodynamics of the sofie Chondrostoma toxostoma (Cyprinidae), With emphasis on early development, $387 \mathrm{p}$.

Gozlan R.E., Copp G.H. and Tourenq J.N., 1999. Comparison of growth plasticity in the laboratory and field, and implications on the onset of juvenile development in the sofie, Chondrostoma toxostoma. Environ. Biol. Fish., 56, 67-77.

Graham C.T., Harrod, C., 2009. Implications of climate change for the fishes of the British Isles. J. Fish Biol., 74, 1143-1205.

Grünbaum T., Cloutier R., Mabee P.M. and Le François N.R., 2007. Early developmental plasticity and integrative responses in arctic charr (Salvelinus alpinus): effects of water velocity on body size and shape. J. Exp. Zool., 308B, 396-408.

Gulidov M.V. and Popova K.S., 1981. The hatching dynamics and morphological features of larvae on roach, Rutilus rutilus in relation to incubation temperature, J. Ichthyol., 1, 87-92.

Gyurko S., Szabo S., Andreka F., Mircea M., Dimoftache M. and Creteanu A., 1957. Reproducera artificiala a cleanului si mrenei la Manastur-Cluj (Artificial reproduction of the chub and barlel in the Manastur-Cluj). Bul. Inst. Cerc. Pisc., 16, 46-52.

Hagen K.H., 1973. Fish behavior related to thermal pollution. Environ. Impact River Mech, 11, 1-23.

Hassler T.J., 1982. Effect of temperature on survival of northern pike embryos and yolk sac larvae. Prog. Fish-Cult., 44, 174-178.

Herzig A. and Winkler H., 1985. Der Einfluss der temperatur auf die embryonale entwicklung der Cypriniden. Oesterreichs Fischerei, 38, 182-196.

Herzig A. and Winkler H., 1986. The influence of temperature on the embryonic development of three cyprinid fishes, Abramis brama, Chalcalburnus chalcoides mento and Vimba vimba. J. Fish Biol., 28, 171-181.

Heugens E.H.W., Hendriks A.J., Dekker T., Van Straalen N.M. and Admiraal W., 2001. A review of the effects of multiple stressors on aquatic organisms and analysis of uncertainty factors of use in risk assessment. Crit. Rev. Toxicol., 31, 247-284.

Hickling R., Roy D.B., Hill J.K., Fox R. and Thomas C.D., 2006. The distributions of a wide range of taxonomic groups are expanding polewards. Glob. Chang. Biol., 12, 450-455. 
Hilge V., 1985. Influence of temperature on the growth of the European catfish (Silurus glanis). Z. Angew Ichthyol., 1, 27-31.

Hokanson K.E.F., 1977. Temperature requirements of some percids and adaptations to the seasonal temperature cycle. J. Fish. Res. Board Can., 34, 1524-1550.

Hokanson K.E.F., McCormick J.H. and Jones B.R., 1973. Temperature requirements for embryos and larvae of the northern pike, Esox lucius (Linnaeus). Trans. Amer. Fish. Soc., 102, 89-100.

Hokanson K.E.F. and Kleiner C.F., 1974. Effects of constant and rising temperature on survival and developmental rates of embryonic and larval yellow perch, Perca flavescens (Mitchill). In: Blaxter J.H.S. (ed.), The Early Life History of Fish, 437-448.

Holcik J., 2003. Rhodeus sericeus (Pallas, 1776). In: Bogutskaya P.B.a.N.G. (ed.), The freshwater fishes of Europe, 81-126.

Holcik J. and Hensel, 1971. Ihtyologika prirucika, Obzor, Bratislava 109-110.

Holcik J. and Hruska V., 1966. On the spawning substrate of the roach - Rutilus rutilus (Linnaeus, 1758) and bream - Abramis brama (Linaeus, 1758) and notes on the ecological characteristic of some european fishes. Vestnik Ceskoslovenske Spolecnosti Zoologicke, 30, 22-29.

Holker H., 2006. Effects of body size and temperature on metabolism of bream compared to sympatric roach. Anim. Biol., 56, 22-37.

Horosewicz L., 1971. Lethal temperatures of roach fry (Rutilus rutilus L.) from lakes with normal and artificially elevated temperature. Polskie Archiwum Hydrobiologii, 18, 69-79.

Horoszewicz L., 1972. The influence of parasites, handling of fish and the methods of investigations on the evaluation of their tolerance and thermal resistance. Rocz Nauk Roln, 94, 35-53.

Horoszewicz L., 1973. Lethal and disturbing temperatures in some fish species from lakes with normal and artificially elevated temperature. J. Fish Biol., 5, 165-181.

Horvart L. and Lucowicz V.M., 1982. Tables with data of hatchery procedures and rearing process of some bred warmwater fishes. Aquacult. Hung., 3, 212-219.

Horvath L., 1977. Improvement of the method for propagation, larval and post-larval rearing of the Wels (Silurus glanis). Aquaculture, 10, 161-167.

Houston A.H., 1982. Thermal effects upon fishes, National Research Council Canada, 200.

Huet M., 1962. Influence du courant sur la distribution des poissons dans les eaux courantes. Rev. Suisse Hydrol., 24, 412-431.

Hynes H.B.N., 1970. The ecology of running waters, Liverpool University Press, Liverpool GBR, 555 p.

Ignatieva G.M. and Kostomarova A.A., 1966. The duration of mitotic cycle at the period of synchronous segmentation (TO) and its dependence on temperature in pack embryos. Dokl. Akad. Nauk SSSR, 168, 1221-1224.

Intergovernmental Panel on Climate Change, 2007. Climate change 2007. Synthesis report. A contribution of Working Groups I, II, and III to the Fourth Assessment Report of the Intergovernmental Panel on Climate Change, Cambridge, UK.

Iwama G.K., Thomas P.T., Forsyth R.B. and Vijayan M.M., 1998. Heat shock protein expression in fish. Rev. Fish Biol. Fisheries, 8, 35-56.

Jobling M., 1981. Temperature tolerance and the final preferendum - rapid methods for the assessment of optimum growth temperatures. J. Fish Biol., 19, 439-455.

Jones E.J.R., 1964. Thermal pollution: the effect of heated effluents, Butterworth and Co. London, 153-168.

Kamler E., 2002. Ontogeny of yolk-feeding fish: an ecological perspective. Rev. Fish Biol. Fisheries, 12 , 79-103.

Kamler E., Keckeis H. and Bauer-Nemeschkal E., 1998. Temperature-induced changes of survival, development and yolk partitioning in Chondrostoma nasus. J. Fish Biol., 53, 658-682.

Kammerer P., 1907. Hybridization of river perch (Perca fluviatilis L.) and ruff (Acerina cernua L.). Arch. Entwicklungsmech. Org., 23, 511-555.

Karas P., 1987. Food consumption, growth and recruitment in perch (Perca fluviatilis L.). Ph.D. thesis, Uppsala University, Uppsala, Sweden, 129 p.

Karas P., 1990. Seasonal changes in growth and standard metabolic rate of juvenile perch, Perca fluviatilis L. J. Fish Biol., 37, 913-920.

Karas P., 1996. Basic abiotic conditions for production of perch (Perca fluviatilis L.) young-of-the-year in the Gulf of Bothnia. Ann. Zool. Fennici, 33, 371-381.

Kaushal S.S., Likens G.E., Jaworski N.A., Pace M.L., Sides A.M., Seekell D., Belt K.T., Secor D.H. and Wingate R.L., 2010. Rising stream and river temperatures in the United States. Front. Ecol. Environ., 8, 461-466. 
Keckeis H., Kamler E., Bauer-Nemeschkal E. and Schneeweiss K., 2001. Survival, development and food energy partitioning of nase larvae and early juveniles at different temperatures. J. Fish Biol., 59, 45-61.

Keith P. and Allardi J., 2001. Atlas des poissons d'eau douce de France, Paris, 387 p.

Keith P., Persat H., Feunteun E. and Allardi J., 2011. Les poissons d'eau douce de France, Biotope, 552 p.

Kennedy B., 1969. Spawning and early development of the dace Leuciscus leuciscus (L.). J. Fish Biol., 1, 249-259.

Kennedy M. and Fitzmaurice P., 1972. Some aspects of the biology of gudgeon Gobio gobio (L.) in Irish waters. J. Fish Biol., 4, 425-440.

Kinouchi T., 2007. Impact of long-term water and energy consumption in Tokyo on wastewater effluent: implications for the thermal degradation of urban streams. Hydrol. Process., 21, 1207-1216.

Kishi D., Murakami M., Nakano S. and Maekawa K., 2005. Water temperature determines strength of top-down control in a stream food web. Freshw. Biol., 50, 1315-1322.

Kokurewicz B., 1969. The influence of temperature on the embryonic development of the perches: Perca fluviatilis (L.) and Lucioperca lucioperca (L.). Zool. Pol., 19, 47-67.

Kolomin Y.M., 1977. The Nadym River ruffe, Acerina cernua. J. Ichthyol., 17, 345-349.

Konečná M., Jurajda P. and Reichard M., 2009. River discharge drives recruitment success of the European bitterling Rhodeus amarus in a regulated river in central Europe. J. Fish Biol., 74, 1642-1650.

Kottelat M. and Freyhof J., 2007. Handbook of European freshwater fishes, Kottelat, Cornol, Switzerland and Freyhof, Berlin, Germany, $646 \mathrm{p}$.

Kovalev P.J., 1973. Natural reproductive conditions of the pike-perch (Lucioperca lucioperca L.), perch (Perca fluviatilis L.) and ruffe (Acerina cernua L.) of lake IImen. J. Ichthyol., 13, 943-946.

Kraiem M.M. and Pattee E., 1980. La tolérance à la température et au déficit en oxygène chez le Barbeau (Barbus barbus L.) et d'autres espèces provenant des zones piscicoles voisines. Arch. Hydrobiol., 88, 250-261.

Krupka I., 1988. Early development of the barbel [Barbus barbus (Linnaeus, 1758)]. Pr. Ustavu Ryb. Hydrobiol. Bratisl., 6, 115-138.

Kryzhanovskii S.G., 1949. Ecological and morphological trends in development of the Cyprinoidae and Siluroidae. Trudy Institute Morfology Zhivotn Akademic Nauk, 1, 332.

Kucharczyk D., Luczynski M., Kujawa R., Kaminski R., Ulikowski D. and Brzuzan P., 1998. Influences of temperature and food on early development of bream (Abramis brama L.). Arch. Hydrobiol., 141, 243-256.

Kucharczyk D., Targoñska K., Zarski D., Kujawa R. and Mamcarz A., 2008. A review of the reproduction biotechnology for fish from the genus Leuciscus. Arch. Pol. Fish., 16, 319-340.

Kupren K., Mamcarz A., Kucharczyk D., Prusińska M. and Krejszeff S., 2008. Influence of water temperature on eggs incubation time and embryonic development of fish from Genus leuciscus. Pol. J. Natl. Sci., 23, 461-481.

Küttel S., Peter A. and Wüest A., 2002. Temperaturpräferenzen und-limiten von Fischarten Schweizerischer Fliessgewässer, Rhône Revitalisierung, Publikation Nummer 1, März, 41 p.

Kwiatkowski M., Zarski D., Kucharczyk D., Kupren K., Jamróz M., Targoñska K., Krejszeff S., HakucBtazowska A., Kujawa R. and Mamcarz A., 2008. Influence of feeding natural and formulated diets on chosen rheophilic cyprinid larvae. Arch. Pol. Fish., 16, 383-396.

L'Abbée-Lund J.H. and Vøllestad L.A., 1985. Homing precision of roach, Rutilus rutilus in lake Arunngen, Norway. Environ. Biol. Fish., 13, 235-239.

Lam T.J., 1983. Environmental influences on gonadal activity, New York and London, Academic Press, 65-116.

Lapkin V.V., Poddubnyy A.G. and Svirskiy A.M., 1983. Thermoadaptive properties of fishes from temperate latitudes. J. Ichthyol., 23, 45-54.

Lappalainen J., 2001. Effects of environmental factors, especially temperature, on the population dynamics of pikeperch (Stizostedion lucioperca L.). In: Department of Limnology and Environmental Protection, $28 \mathrm{p}$.

Lappalainen J., Dörner H. and Wysujack K., 2003. Reproduction biology of pikeperch (Sander lucioperca (L.) - a review. Ecol. Freshw. Fish., 12, 95-106.

Leblanc R.T., Brown R.D. and Fitzgibbon J.E., 1997. Modeling the effects of land use change on the water temperature in unregulated urban streams. J. Environ. Manage., 49, 445-469.

Lelek A., 1987. Threatened fishes of Europe. The freshwater fishes of Europe, Aula-Verlag, Wiesbaden, $343 \mathrm{p}$. 
Lelek A. and Penáz M., 1963. Spawning of Chondrostoma nasus (L.) in the Brumovka River, S. Zool. Listy., 12, 121-134.

Lepičová A., Hamáčková J. and Lepič P., 2002. Rearing of early fry (Leuciscus leuciscus L.) under controlled conditions. Bul. Vurh Vodnany, 37, 16-23.

Leynaud G., 1967. Les pollutions thermiques - Influence de la température sur la vie aquatique. Bulletin Technique d'Information, 224, 25.

Leynaud G. and Allardi J., 1974. Incidences d'un rejet thermique en milieu fluvial sur les mouvements des populations ichtyologiques. Bull. Fr. Piscic., 255, 41-50.

Lillelund K., 1966. Versuche zur erbrutung der eier vom hecht. Esox lucius in, Abhangigkiet von Temperatur und Licht. Arch. Fishereiwess, 17, 95-113.

Lindroth A., 1946. Zur Biologie der Befruchtung und Entwicklung beim Hecht. Mitt. Anst. Binnenfischerei Drottningholm, 24, 1-173.

Löffler H., 1982. Zur Ökologie des Brachsen (Abramis brama L.) im Bodensee. In: Universität Tübingen.

Lusk S., 1967. Population dynamics of Chondrostoma nasus (Linnaeus, 1758) in the Rokytna river. Acta Scientarum Naturalium Brno, 1, 473-522.

Lusk S., 1995. Influence of valley dams on the changes in fish communities inhabiting streams in the Dyje River drainage area. Folia Zool., 44, 45-56.

Lutterschmidt W.I. and Hutchison V.H., 1998. The critical thermal maximum: history and critique. Can. J. Zool., 75, 1561-1574.

Machniak K., 1975. The effects of hydroelectric development on the biology of northern fishes, III: Walleye, Stizostedion vitreum vitreum: A literature review and bibliography, Canadian Fisheries Marine Service, $68 \mathrm{p}$.

Magnuson J.J., Crowder L.B. and Medvick P.A., 1979. Temperature as an ecological resource. Amer. Zool., 19, 331-343.

Maier K.J., Zeh M., Ortlepp J. and Zbinden S., 1995. Distribution et reproduction des espèces du genre Chondrostoma en Suisse : le nase (C. nasus), la sofie (C. toxostoma), la savetta (C. soetta). Office fédéral de l'environnement, des forêts et du paysage, $62 \mathrm{p}$.

Mamcarz A., Kupren K., Kucharczyk D. and Kujawa R., 2005. Influence of temperature on, body size and yolk sac volumes of three larval rheophilic cyprinids (genus Leuciscus). Eur. Aquacult. Soc., Spec. Publ., 36, 310-313.

Mann R.H.K., 1974. Observations on the age, growth, reproduction and food of the dace Leuciscus leuciscus (L.), in two rivers in southern England. J. Fish Biol., 6, 237-253.

Mann R.H.K., 1996. Environmental requirements of European non-salmonid fish in rivers. Hydrobiologia, 323, 223-235.

Mann R.H.K. and Bass J.A.B., 1997. The critical water velocities of larval roach (Rutilus rutilus) and dace (Leuciscus leuciscus) and implications for river management. Regul. Rivers: Res. Mgmt., 13, 295-301.

Marcy B.C.J., 1976. Fishes of the lower Connecticut river and the effects of the Connecticut yankee plant. In: Thorpe D.M.a.L.M. (ed.), The Connecticut river ecological study - The impact of a nuclear power plant, 61-139.

Marcy B.C. and Jacobson P.M., 1976. Early life history studies of american shad in the lower Connecticut River and effects of the Connecticut yankee plant. In : Merriman D. and Thorpe L.M. (eds.), The Connecticut River Ecological Study, The Impact of a Nuclear Power Plant, American Fisheries Society Monograph No. 1, p 141-168.

Matthews W.J. and Maness J.D., 1979. Critical thermal maxima, oxygen tolerance and success of cyprinid fishes in a southwestern river. Am. Midl. Nat., 374-377.

Mc Cauley R.W. and Casselman J.M., 1981. The final preferendum as an index of the temperature for optimum growth in fish. In: Tiews B.K. (ed.), World Symposium on Aquaculture in Heated Effluents and Recirculation Systems, Heenemann Verlagsgesellschaft, 81-93.

Middaugh D.P., Davis W.R. and Yokum R.L., 1975. The response of larval fish, Leiostomus xanthurus, to environmental stress following sublethal cadmium exposure, Contrib. Mar. Sci., 19, 13-19.

Mihalik J., 1982. Der Wels, Die Neue Brehm-Bücherei, 71 p.

Miller S.W., Wooster D. and Li J., 2007. Resistance and resilience of macroinvertebrates to irrigation water withdrawals. Freshw. Biol., 52, 2494-2510.

Millet, 1989. Étude morphométrique et scalimétrique des stocks de vandoises du Rhône et de l'Ain Utilisation dans le marquage biologique, $120 \mathrm{p}$.

Mills C.A., 1980. Spawning and rearing eggs of the dace. Fish. Manage., 11, 67-72. 
Mills C.A., 1981. Egg population dynamics of naturally spawning dace, Leuciscus leuciscus (L.). Environ. Biol. Fish., 6, 151-158.

Mills C.A., 1991. Reproduction and life history, Chapman and Hall, London, 483-508.

Mohr E., 1957. Der Wels, Die neue Bücherei, A. Ziemsen Verlag, Wittenberg Lutherstadt, 44 p.

Moore R.D., Spittlehouse D.L. and Story A., 2005. Riparian microclimate and stream temperature response to forest harvesting: A review. J. Am. Water Resour. Assoc., 41, 813-834.

Mouthon J. and Daufresne M., 2006. Effects of the 2003 heatwave and climatic warming on mollusc communities of the Saône: a large lowland river and of its two main tributaries (France). Global Change Biol., 12, 441-449.

Müller R., 1997. Vorlesungsskript Fischkunde der Schweiz 1997/1998.

Muntyan S.P., 1967. Effect of constant incubation temperatures on the hatching process and on the morphological characteristics of pike-perch embryos. Trezisy Dokl. Vses. Soveshch. po ekol. i fiziol. ryb. Nauka, 135-140.

Neill W.H., 1974. Distributional ecology and behavioral thermoregulation of fishes. Trans. Am. Fish. Soc., 103, 663-710.

Neophitou C. and Giapis A.J., 1994. A study of the biology of pumpkinseed (Lepomis gibbosus L.) in Lake Kerkini (Greece). J. Appl. Ichthyol., 10, 123-133.

Noges P. and Jarvet A., 2005. Climate driven changes in the spawning of roach (Rutilus rutilus L.) and bream (Abramis brama L.) in the Estonian part of the Narva River basin. Boreal Environ. Res., 10, 45-55.

Nzau Matondo B., Ovidio M., Poncin P., Kakesa T.A., Wamuini L.S. and Philippart J.-C., 2007. Hybridization success of three common European cyprinid species, Rutilus rutilus, Blicca bjoerkna and Abramis brama and larval resistance to stress tests. Fish. Sci., 73, 1137-1146.

Ogle D.H., 1998. A Synopsis of the Biology and Life History of Ruffe. J. Geart. Lakes Res., 24, 170-185.

Ojanguren A.F. and Brana F., 2000. Thermal dependence of swimming endurance in juvenile brown trout. J. Fish Biol., 56, 1342-1347.

Olden J.D. and Naiman R.J., 2010. Incorporating thermal regimes into environmental flows assessments: Modifying dam operations to restore freshwater ecosystem integrity. Freshwater Biol., 55, 86-107.

Omarov O.P. and Popova O.A., 1985. Feeding behaviour of pike, Esox lucius, and catfish, Silurus glanis, in the Arakum Reservoirs of Dagestan, J. Ichthyol., 25, 25-36.

Ovidio M. and Philippart J.C., 2005. Long range seasonal movements of northern pike (Esox lucius L.) in the barbel zone of the River Ourthe (River Meuse basin, Belgium). In: Spedicato G.M.T.L., Marmulla G. (eds.), Aquatic telemetry: advances and applications. Proceedings of the Fifth Conference on Fish Telemetry held in Europe, $295 \mathrm{p}$.

Papadopol M. and Cristofor S., 1980. Recherches sur l'écologie de deux populations de spirlin, Alburnoides B. bipunctatus (Bloch), des eaux de la Roumanie (Pisces, Cyprinidae). Trav. Mus. Hist. Nat. "Grigore Antipa”, XXII, 483-493.

Peczalska A., 1979. Fishery and some problems of the biology of the white bream in the firth of Szczecin. Prade MIR, 17, 145-157.

Pelz G.R., 1986. Der Schneider, Allg. Fischereizeitung Fischwaid.

Penáz M., 1973. Embryonic development of the Barb, Barbus barbus (Linnaeus, 1978). S. Zool. Listy., 22, 363-374.

Penáz M., 1974a. Early development of the nase carp, Chondrostoma nasus (Linnaeus, 1758). S. Zool. Listy., 23, 275-288.

Penáz M., 1974b. Influence of water temperature on incubation and hatching in Chondrostoma nasus (Linnaeus, 1758). S. Zool. Listy., 23, 53-59.

Penáz M. and Sterba O., 1969. Notes to the incubation period, growth and mortality of the chub, Leuciscus cephalus (Linne, 1758), in the early life-history stages. Vestnik Ceskoslovenske Spolecnosti Zoologicke, 33, 56-70.

Penáz M., Lusk S. and Povz M., 1995. Age and size structure of nase spawning shoals in the artificial spawning canal on the River Sava at Mavcice, Slovenia. Folia Zool., 44 (Suppl. 1), 35-42.

Perche, 1948. Les chondrostomes : le hotu, la soiffe. L'hameçon, 27, 11-173.

Petersen J.H. and Kitchell J.F., 2001. Climate regimes and water temperature changes in the Columbia River: bioenergetic implications for predators of juvenile salmon. Can. J. Fish. Aquat. Sci., 58, 1831-1841. 
Philippart J.C., 1980. Démographie du hotu, Chondrostoma nasus (Linné) (Teleostei: Cyprinidae) dans l'Ourthe (bassin de la Meuse, Belgique). Annales de la Société Royale de Zoologie, Belgique, 110, 199-219.

Philippart J.C., 1981. Ecologie d'une population de vandoise, Leuciscus leuciscus L. dans la rivière Ourthe (bassin de la Meuse, Belgique). Ann. Limnol., 17, 41-62.

Philippart J.C., Lambert J.M. and Baras E., 1989. Étude de la conservation, de l'amélioration et de la restauration des habitats utilisables par les poissons de rivière, Rapport final à la Région Wallonne (Conservation de la Nature), 1, 74 p. ; 72, 87 p. ; 73, 86 p.

Poltavchuk M.A., 1965. Biologia i rozvedenie dneprovskogo sudaka v zamknutvkh vodoemov, Naukowa dumka.

Poncin P., 1996. Reproduction chez nos poissons, Nelles Imprimeries Havaux, 80 p.

Prignon C., Micha J.C. and Gillet A., 1988. Biological and environmental characteristics of fish passage at the Tailfer Dam on the Meuse River, Belgium. Trans. Amer. Fish. Soc., 69-84.

Prokes M. and Penáz M., 1978. The course of spawning, early development and longitudinal growth of the nase carp, Chondrostoma nasus, in the Rokytna and Jihlaya rivers. Folia Zool., 27, 269-278.

Quinn T.P. and Adams D.J., 1996. Environmental changes affecting the migratory timing of american shad and sockeye salmon. Ecology, 77, 1151-1162.

Raat A.J.P., 1988. Synopsis of biological data on the northern pike Esox lucius Linnaeus, 1758, 2nd Revision edition, Rome, FAO Fish. Synop., 30, 178 p.

Raikova-Petrova G. and Divkov M., 1998. Maturity, spawning and sex ratio of pike perch, Stizostedion lucioperca (L.), in two Bulgarian reservoirs as compared to other European habitats. J. Appl. Ichthyol., 14, 31-35.

Reutter J.M. and Herdendorf C.E., 1974. Environmental evaluation of a nuclear power plant on Lake Erie, U. S. Fish and Wildlife Service, $84 \mathrm{p}$.

Reutter J.M. and Herdendorf C.E., 1976. Thermal discharge from a nuclear power plant: predicted effects on lake Erie fish. Ohio J. Sci., 76, 39-45.

Roenko, 1965. White bream of Volgogradskoye dam reservoir. Tr. Saratov. Otd. NII Ozer. Rech. Ryb. Khoz., 8, 163-170.

Rombough P.J., 1997. The effects of temperature on embryonic and larval development. In: C.M.M. Wood D.M. (ed.), Global Warming: Implications for Freshwater and Marine Fish.

Saat T. and Veersalu A., 1996. The rate of early development in perch Perca fluviatilis L. and ruffe Gymnocephalus cernuus (L.) at different temperatures. Ann. Zool. Fennici, 33, 693-698.

Schaefer J. and Ryan A., 2006. Developmental plasticity in the thermal tolerance of zebrafish Danio rerio. J. Fish Biol., 69, 722-734.

Schiemer F., Keckeis H. and Kamler E., 2003. The early life history stages of riverine fish: ecophysiological and environmental bottlenecks. Comp. Biochem. Physiol. Pt. A, 133, 439-449.

Schiemer F., Keckeis H., Nemeschkal H., Schludermann E., Winkler G. and Zweimuller I., 2004. Ontogenetic patterns in thermal adaptation of fish vs. long-term temperature trends in large rivers. Int. Congr., 1275, 209-217.

Schlumberger O., Sagliocco M. and Proteau J.P., 2001. Biogéographie du Silure glane (Silurus glanis) : causes hydrographiques, climatiques et anthropiques. Bull. Fr. Pêche Piscic., 357-360, 533-547.

Schwarz M., 1996. Verbreitung und Habitatanprüche des Strömers (Leuciscus souffia Risso 1826) in den Fliessgewässern der Schweiz, Diplomarbeit 10345, EAWAG (Kastanienbaum), Universität Freiburg, $112 \mathrm{p}$.

Scott D.P., 1964. Thermal resistance of pike (Esox lucius L.), muskellunge (E. masquinongy Mitchill), and their F1 hybrid. J. Fish. Res. Board Can., 21, 1043-1049.

Shiri Harzevili A., De Charleroy D., Auwerx J., Vught I. and Van Slycken J., 2003. Larval rearing of chub, Leuciscus cephalus (L.), using decapsulated Artemia as direct food. J. Appl. Ichthyol., 19, 123-125.

Shkorbatov G.L., 1964. Nauch. Dokl. Wysh. Shkoly Biolog. Nauki., 2, 60-65.

Spillmann C.J., 1961. Poissons d'eau douce, Paul Lechevalier, Paris, 303 p.

Spillmann J., 1962. Sur la systématique de telestes soufia risso. Variation de certains caractères numériques et métrique de l'espèce. Bulletin du Museum National d'Histoire Naturelle, 34, 435-452.

Spurny P., Fiala J. and Mares J., 2004. Intensive rearing of the nase Chondrostoma nasus (L.) larvae using dry starter feeds and natural diet under controlled conditions, Czech J. Snimisà, 49, 444-449. 
Stankovitch S., 1921. Étude sur la morphologie et la nutrition des alevins de poissons cyprinidés. Travaux du laboratoire de pisciculture de l'université de Grenoble, XIII ${ }^{\mathrm{e}}$ année (fascicule unique), $1-182$.

Statova M.P., 1973. Sexual maturity, reproduction and fecundity. In: Kuchurganskij liman-okhladitel Moldavsky, 148-149.

Steffens W., 1976. Zeitschrift fur die Binnenfischerei der DDR, 23, 327-343, 360-371.

Swift D.R., 1965. Effect of the temperature on mortality and rate of development of the eggs of the pike (Esox lucius L.) and the perch (Perca fluviatilis L.). Nature, 206, 528.

Talmage S.S., 1977. Thermal effects on aquatic organisms: an annotated bibliography of the 1977 literature, The Ecological Sciences Information Center, $179 \mathrm{p}$.

Tarkan A.S., Gaygusuz O., Gürsoy C. and Acipinar H., 2005. Life History Pattern of an Eurasian Cyprinid, Rhodeus amarus, in a Large Drinking-Water System (Ömerli Dam Lake-Istanbul, Turkey). J. Black Sea/Mediterranean Environment, 11, 205-224.

Teletchea F., 2011. Guide des poissons de France - Cours d'eau, lacs et étangs, Belin, 240 p.

Teletchea F., Fostier A., Le Bail P.Y., Jalabert B., Gardeur J.N. and Fontaine P., 2007. STOREFISH: A new database dedicated to the reproduction of temperate freshwater teleost fishes. Cybium, 31, 227-235.

Teletchea F., Gardeur J.N., Kamler E. and Fontaine P., 2009a. The relationship of ovocyte diameter and incubation temperature to incubation time in temperate freshwater fish species. J. Fish Biol., 74, 652-668.

Teletchea F., Fostier A., Kamler E., Gardeur J.N., Le Bail P.Y., Jalabert B. and Fontaine P., 2009b. Comparative analysis of reproductive traits in 65 freshwater fish species: application to the domestication of new fish species. Rev. Fish Biol. Fisheries, 19, 403-430.

Thorpe J.E., 1977a. Morphology, physiology, behaviour and ecology of Perca fluviatilis L. and Perca flavescens Mitchill. J. Fish. Res. Board Can., 34, 1504-1514.

Thorpe J.E., 1977b. Synopsis of biological data on the perch Perca fluviatilis (Linnaeus, 1758) and Perca flavescens (Mitchell, 1814), FAO Fish. Synop., 113, 138 p.

Tocko M.N., 1987. The development and nutrition of the young cyprinids of Lake Ohriod I, Special Edition, Hydrobiological Insitute, Ohrid, 1-165.

Todd A.S., Coleman M.A., Konowal A.M., May M.K., S. Johnson, Vieira N.K.M. and saunders J.F., 2008. Development of New Water temperature Criteria to Protect Colorado's Fisheries. Am. Fish. Soc. Spec. Publ., 33, 433-443.

Torgersen C.E., Price D.M., Li H.W. and Mclntosch B.A., 1999. Multiscale thermal refugia and stream habitat associations of chinook salmon in Northeastern Oregon. Ecol. Appl., 9, 301-319.

Torgersen C.E., Faux R.N., Mclntosh B.A., Poage N.J. and Norton D.J., 2001. Airborne thermal remote sensing for water temperature assessment in rivers and streams. Rem. Sens. Environ., 76, 386-398.

Toth E.O., Gulyas P. and Olah J., 1982. Effect of temperature on growth, food conversion, and survival of sheatfish (Silurus glanis L.) and common carp (Cyprinus carpio L.) at sublethal ammonia concentration. Aquacult. Hung., 3, 51-56.

Trembley F.J., 1960. Research project on effects of condenser discharge water on aquatic life, The institute of Research, Lehigh University.

Tseitlin V.B., 1980. Duration of gastric digestion in fishes. Mar. Ecol. Progr., 2, 277-280.

Urho L., 1996. Habitat Shifts of perch larvae as survival strategy. Ann. Zool. Fennici, 33, 329-340.

Vallod D., 1987. Le silure (Silurus glanis, L.), ADAPRA, Lyon, 40 p.

Varley M.E., 1967. British Freshwater Fishes - Factors Affecting their Distribution, London.

Verneaux J., 1981. Les poissons et la qualité des cours d'eau. Annales Scientifiques de I'Université de Franche-Comté (Besançon), 4, 26-41.

Vladimirov M.Z. and Bodareu M.N., 1975. Embryological development of the barbel (Barbus barbus), Biol. Resur. Vod. Maldov., 13, 123-139.

Wagner C., Wahl P. and David H., 2007. Evaluation of temperature-selection differences among juvenile muskellunge originating from different latitudes. Environ. Biol. Fish., 79, 85-98.

Wang N. and Eckmann R., 1994. Effects of temperature and food density on egg development, larval survival and growth of perch (Perca fluviatilis L). Aquaculture, 122, 323-333.

Wapora I., 1977. Report on the water quality and biological data in the vicinity of the Syl Laskin electric power station, Appendix A, Washington D.C., 227 p.

Watenpaugh D.E., Beitinger T.L. and Huey D.W., 1985. Temperature tolerance of nitrite-exposed channel catfish. Trans. Amer. Fish. Soc., 114, 274-278. 
Weatherley A.H., 1973. Thermal stress and interrenal tissue in the perh, Perca fluviatilis (Linnaeus), Proc. Zool. Soc. Lon., 141, 527-555.

Webb B.W., 1996. Trends in stream and river temperature. Hydrol. Process., 10, 205-226.

Wieser W., Forstner H., Schiemer F. and Mark W., 1988. Growth rates and growth efficiencies in larvae and juveniles of Rutilus rutilus and other cyprinid species: effects of temperature and food in the laboratory and in the field. Can. J. Fish. Aquat. Sci., 45, 943-950.

Wiliamson J.H., Carmichael G.J., Graves K.G., Simco B.A. and Tomasso J.R.J., 1993. Centrarchids. In: Stickney R.R. (ed.), Culture of nonsalmonid freshwater fishes, 145-198.

Willemsen J., 1959. Research of the production of northern pike, 58-65.

Willemsen J., 1977. The influence of temperature on feeding, growth and mortality of pikeperch and perch. Verh. Internat. Verein. Limnol., 20, 2127-2133.

Wohlgemuth E., 1981. Nekteré vlastnosti populace horavky duhové (Rhodeus sericeus) z reky Jihlavy. Acta Sci. Nat. Mus. Moraviae Occid. Trebíc, 12, 29-34.

Wolnicki J. and Gorni W., 1994. Termiczne optimum wzrostu młodocianej winki, Chondrostoma nasus L. Komunikaty Rybackie, 2, 18-19.

Wolnicki J. and Myszkowski L., 1999. Larval rearing of reophilic cyprinids, Aspius aspius L. and Leuciscus cephalus L., on live, dry or mixed diet. Eur. Aquac. Soc., Spec. Publ., 27, 258-259.

Wolter C., 2007. Temperature influence on the fish assemblage structure in a large lowland river, the lower Oder River, Germany. Ecol. Freshwater Fish., 16, 493-503.

Woynarovich E. and Horvath L., 1981. La reproduction artificielle des poissons en eau chaude : manuel de vulgarisation, FAO, $191 \mathrm{p}$.

Wurtz-Arlet J., 1950. Quelques observations sur la biologie de la vandoise (Leuciscus leuciscus L.). Bull. Fr. Piscic., 158, 14-18.

Wüstemann O. and Kammerad B., 1995. Der Hasel Leuciscus leuciscus. Die Neue Brehm-Bücherei.

Yildirim A., Erdogan O., Turkmen M. and Demir B.C., 1999. The investigation of some reproduction characteristics of the Alburnoides bipunctatus fasciatis (Nordman, 1840) living in Oltu Stream, Coruh Basin. Turk. J. Vet. Anim. Sci., 23, 679-686.

Zahn M., 1963. Jahreszeitliche Veranderungen der Vorzugstemperaturen von Scholle (Pieuronectes platessa Linne) und Bitterling (Rhodeus sericeus Pallas). Verh. Dt. Zool. Ges., 562-580.

Zarski D., Kucharczyk D., Kwiatkowski M., Targoñska K., Kupren K., Krejszeff S., Jamróz M., HakucBtazowska A., Kujawa R. and Mamcarz A., 2008. The effect of stocking density on the growth and survival of larval asp, Apsius aspius (L.) and european chub, Leuciscus leuciscus L., during rearing under controlled conditions. Arch. Pol. Fish., 16, 371-381.

Zhdanova N.N., 1966. Lethal temperature limit, and depths required for the artificial rearing of young pike-perch. Tr. Azov. Nauch. Issled. Inst. Rybn. Khoz., 8, 79-88.

\section{Web sites}

Fishbase data:

http://www.fishbase.org/

Minnesota University, USA (Ruffe data):

http://fwcb.cfans.umn.edu/research/ruffe/ginfo/ginfo.htm

Natura 2000 on the web site of Ministry of Ecology, France:

Vairone/Blageon:

http://www.ecologie.gouv.fr/IMG/natura2000/habitats/pdf/tome7/1131.pdf

French Nase/Toxostome: http://www.ecologie.gouv.fr/IMG/natura2000/habitats/pdf/tome7/1126.pdf

Bitterling/Bouvière:

http://www.ecologie.gouv.fr/IMG/natura2000/habitats/pdf/tome7/1134.pdf

\section{APPENDIX}

Table. Data and bibliographic references detailed for the 19 species. 


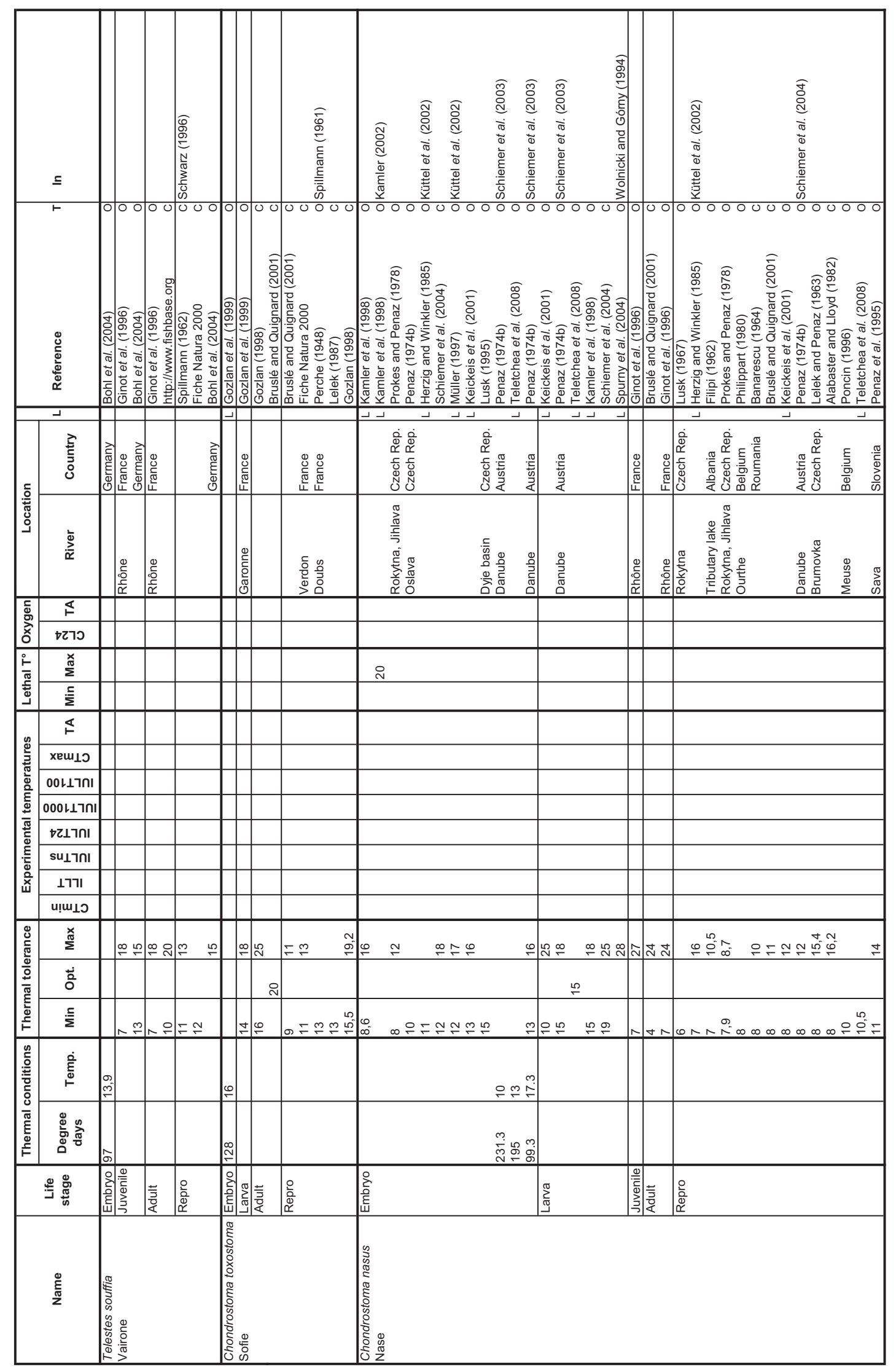




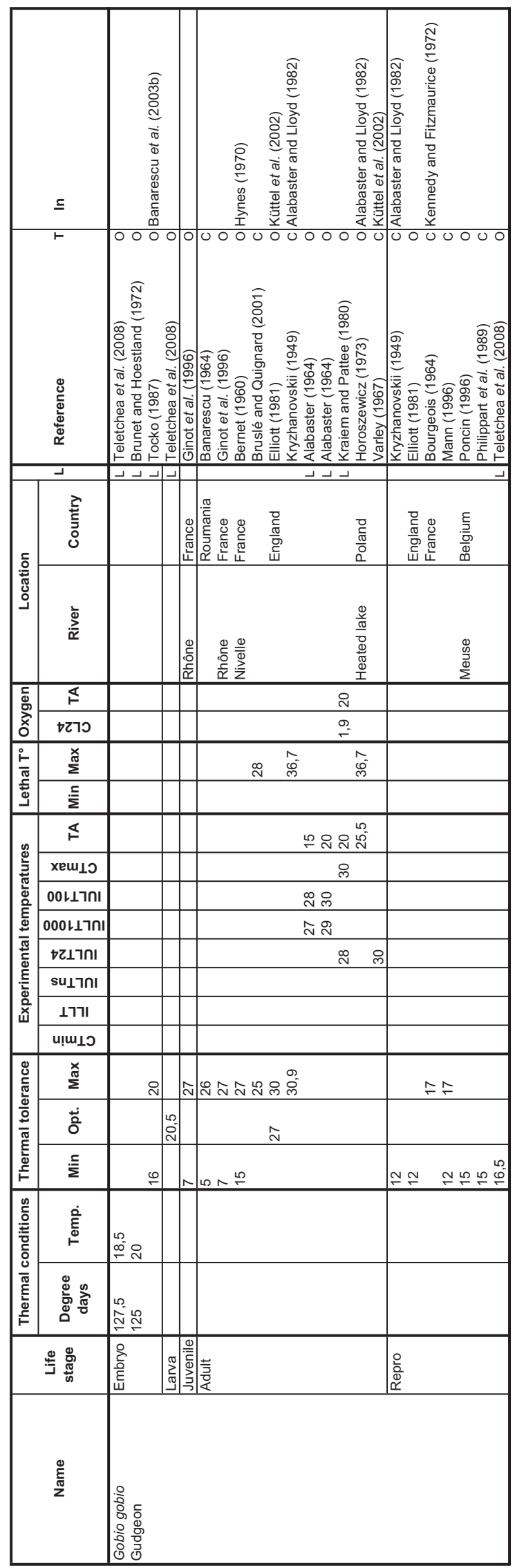




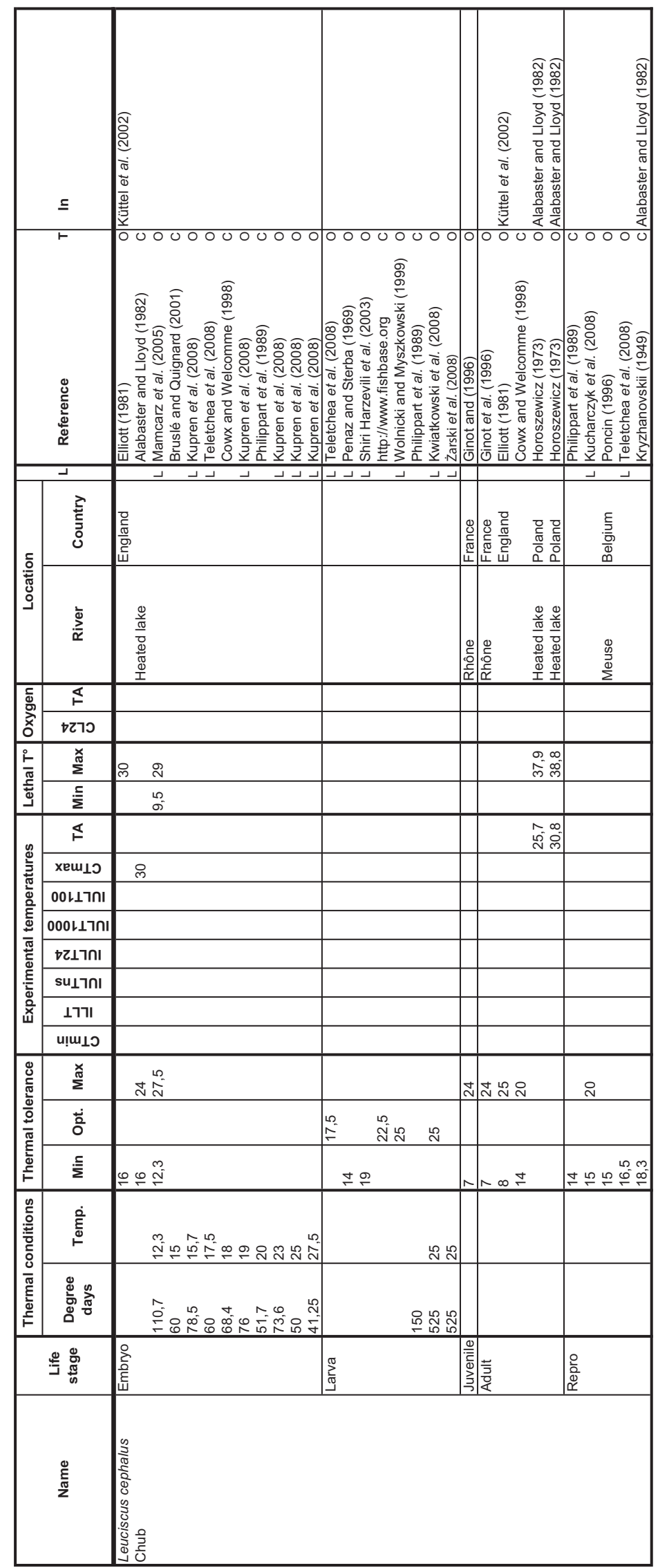




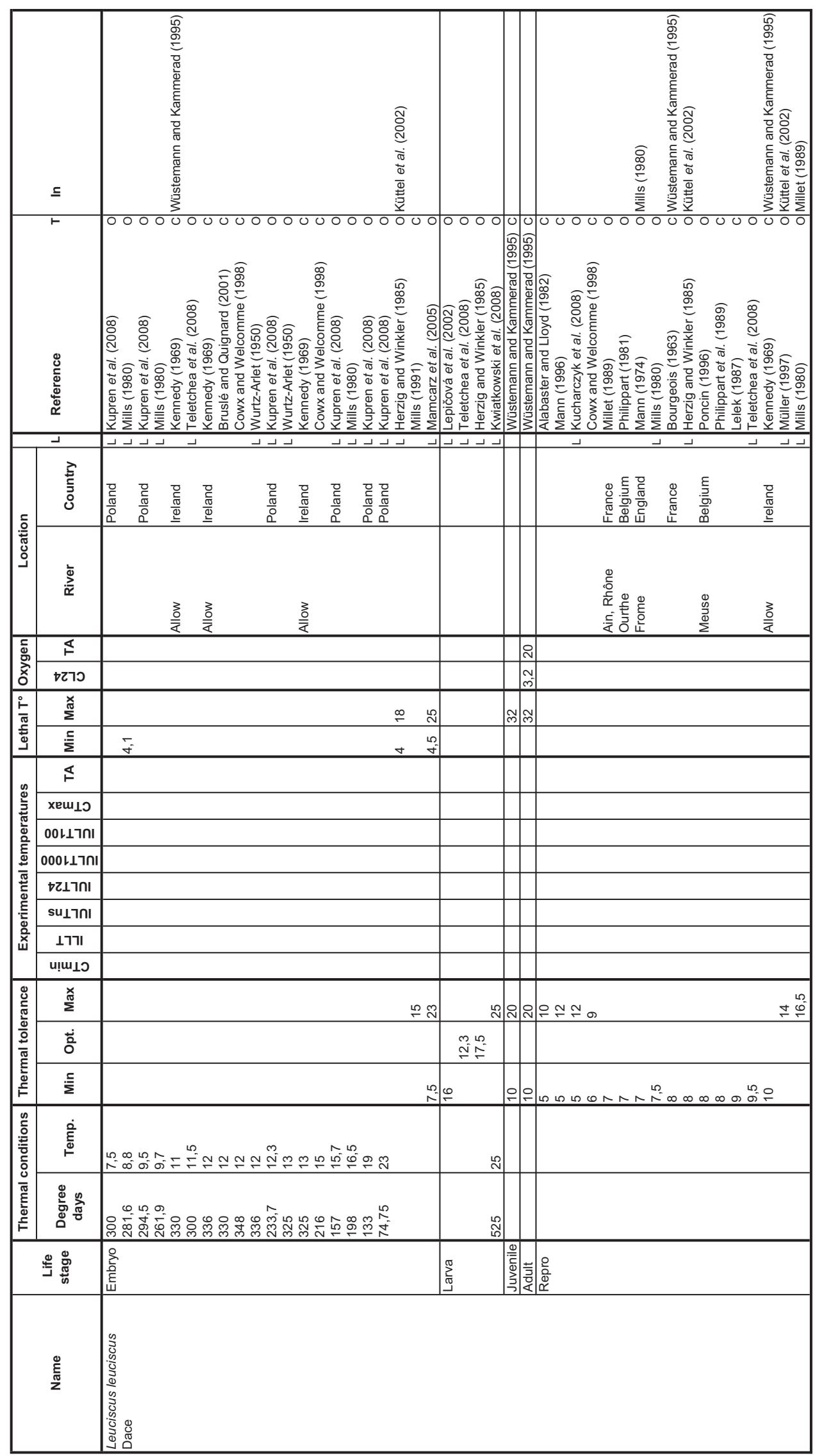




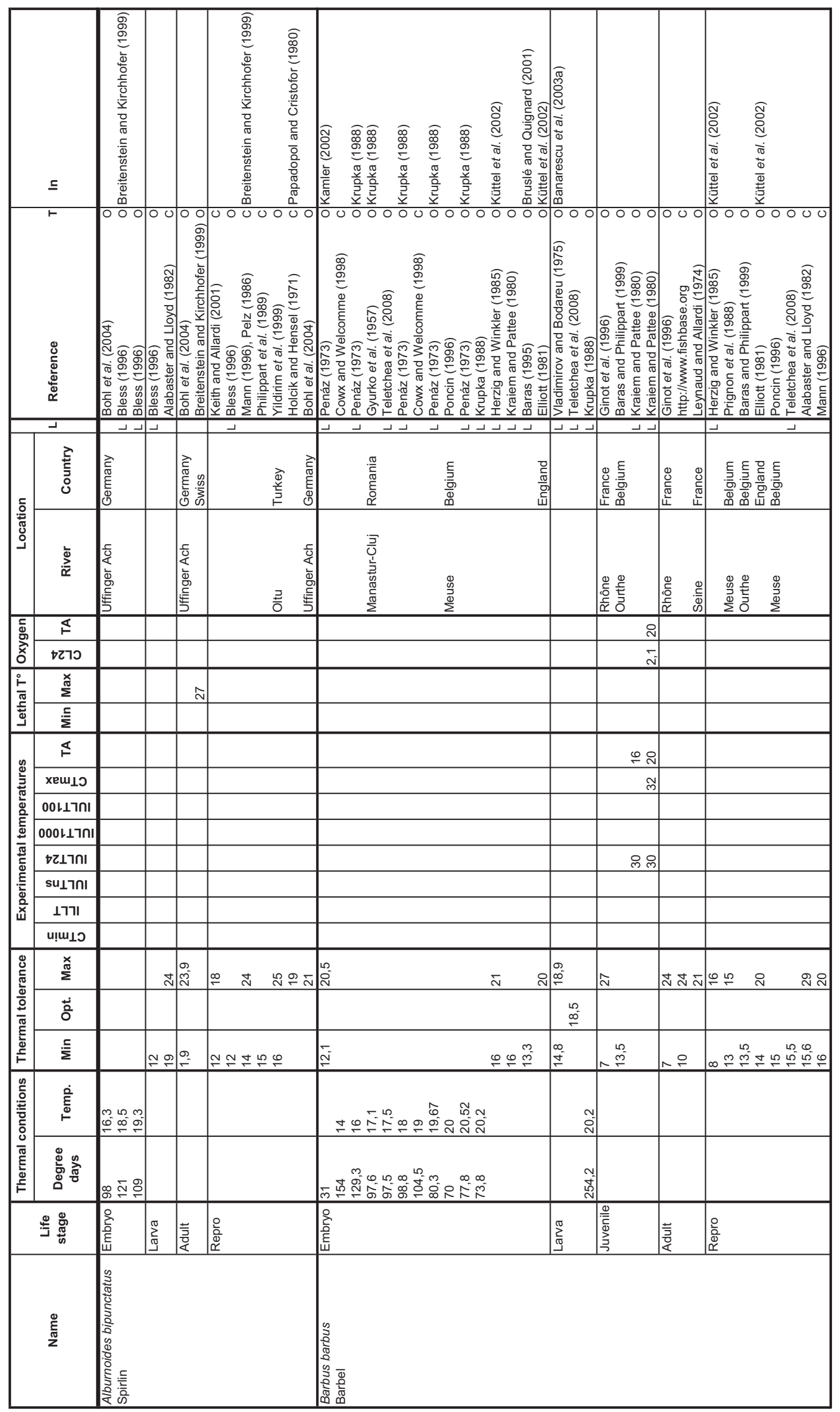




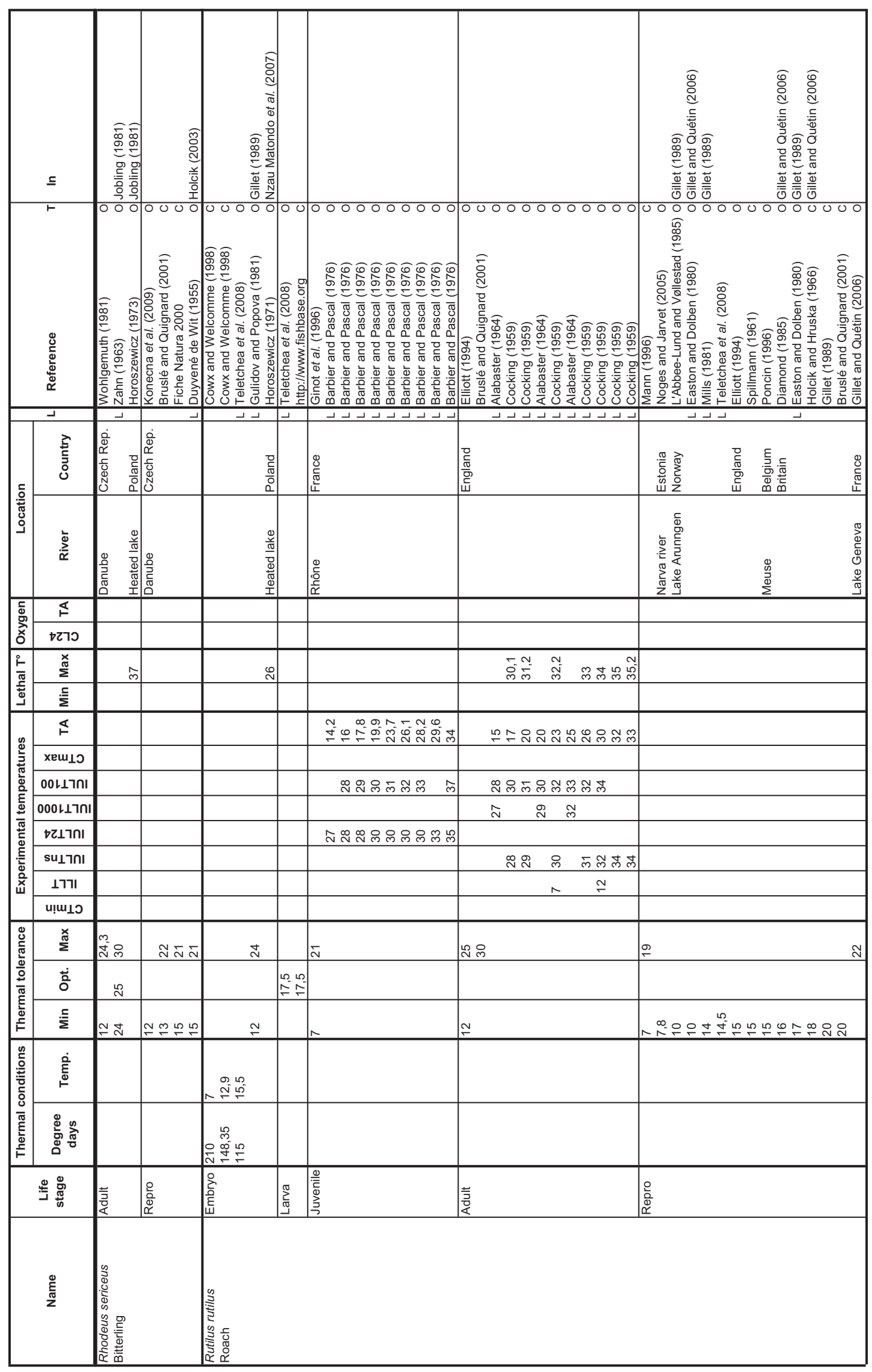




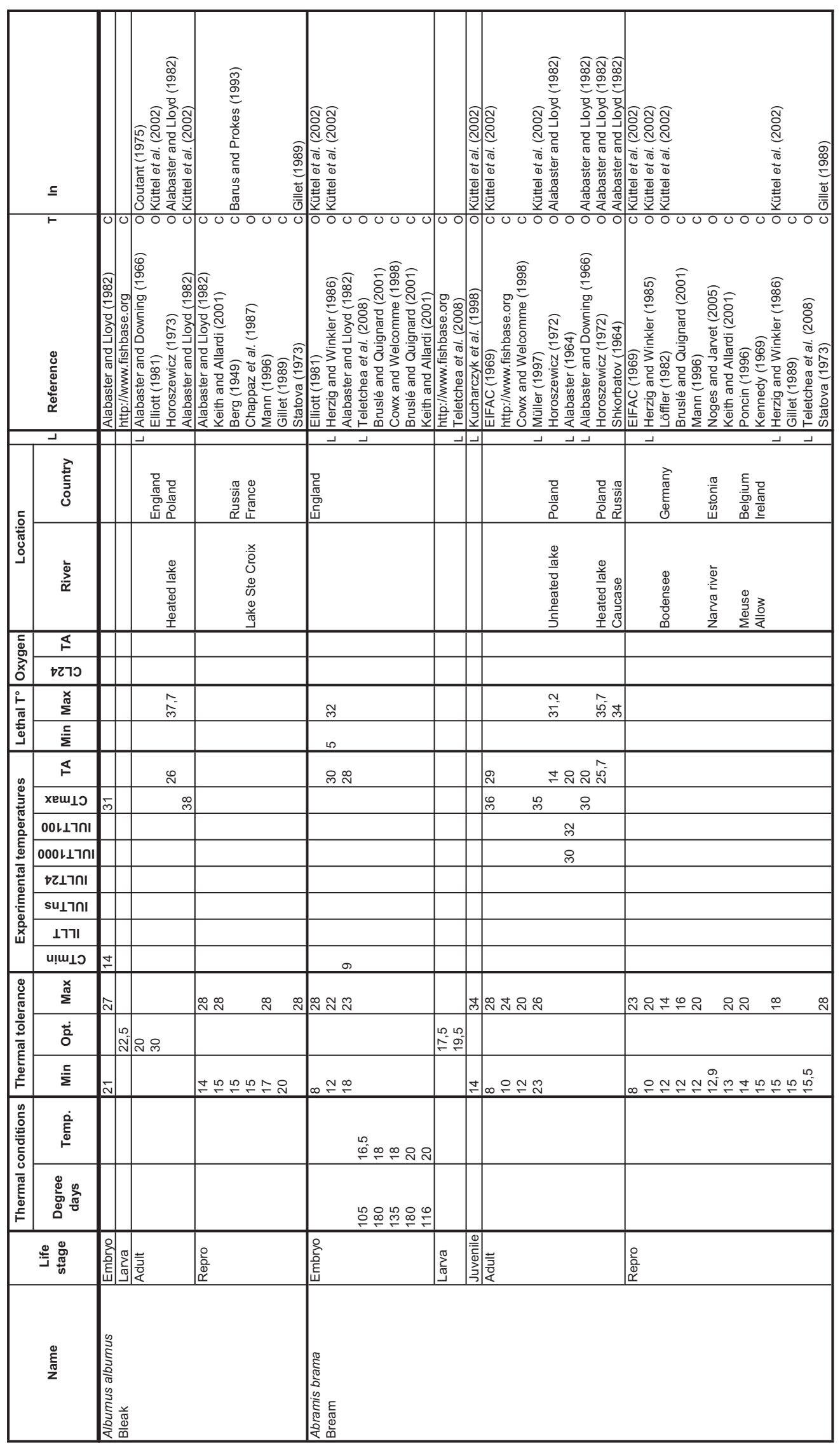




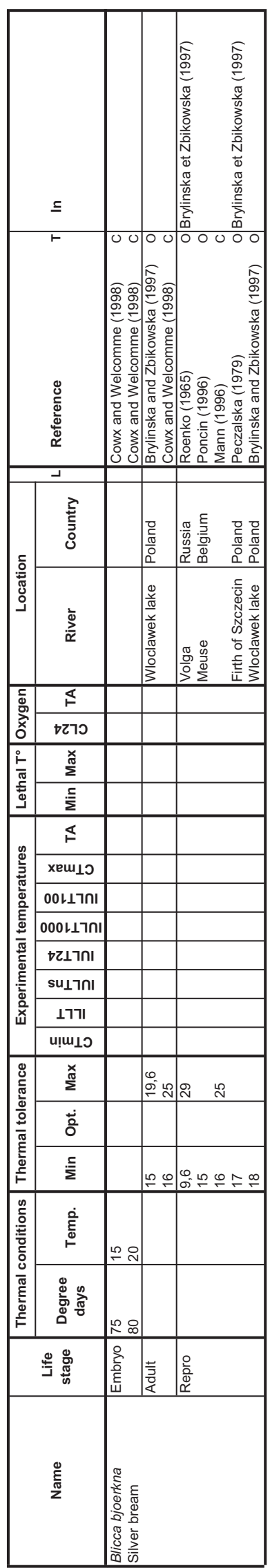




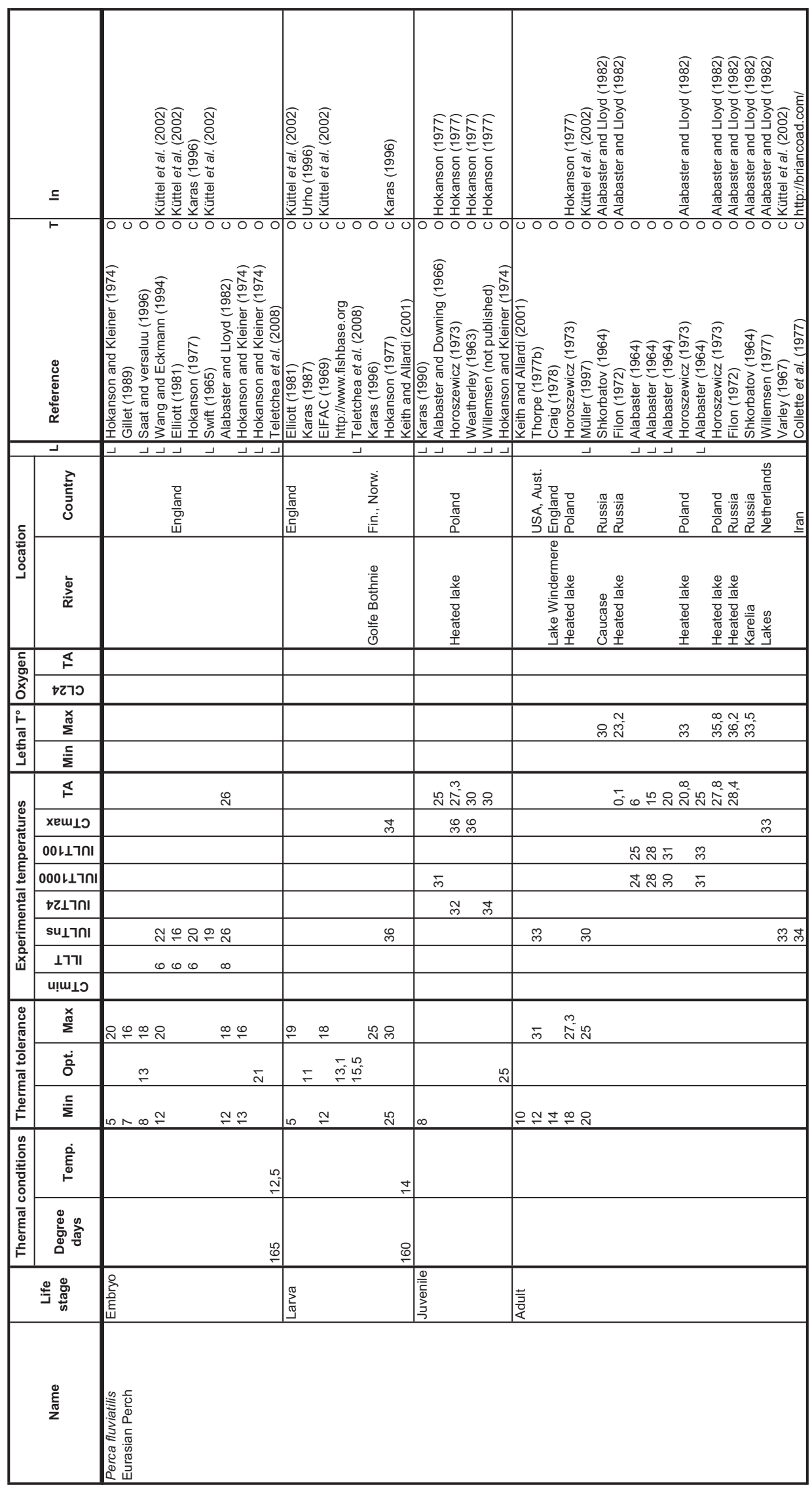




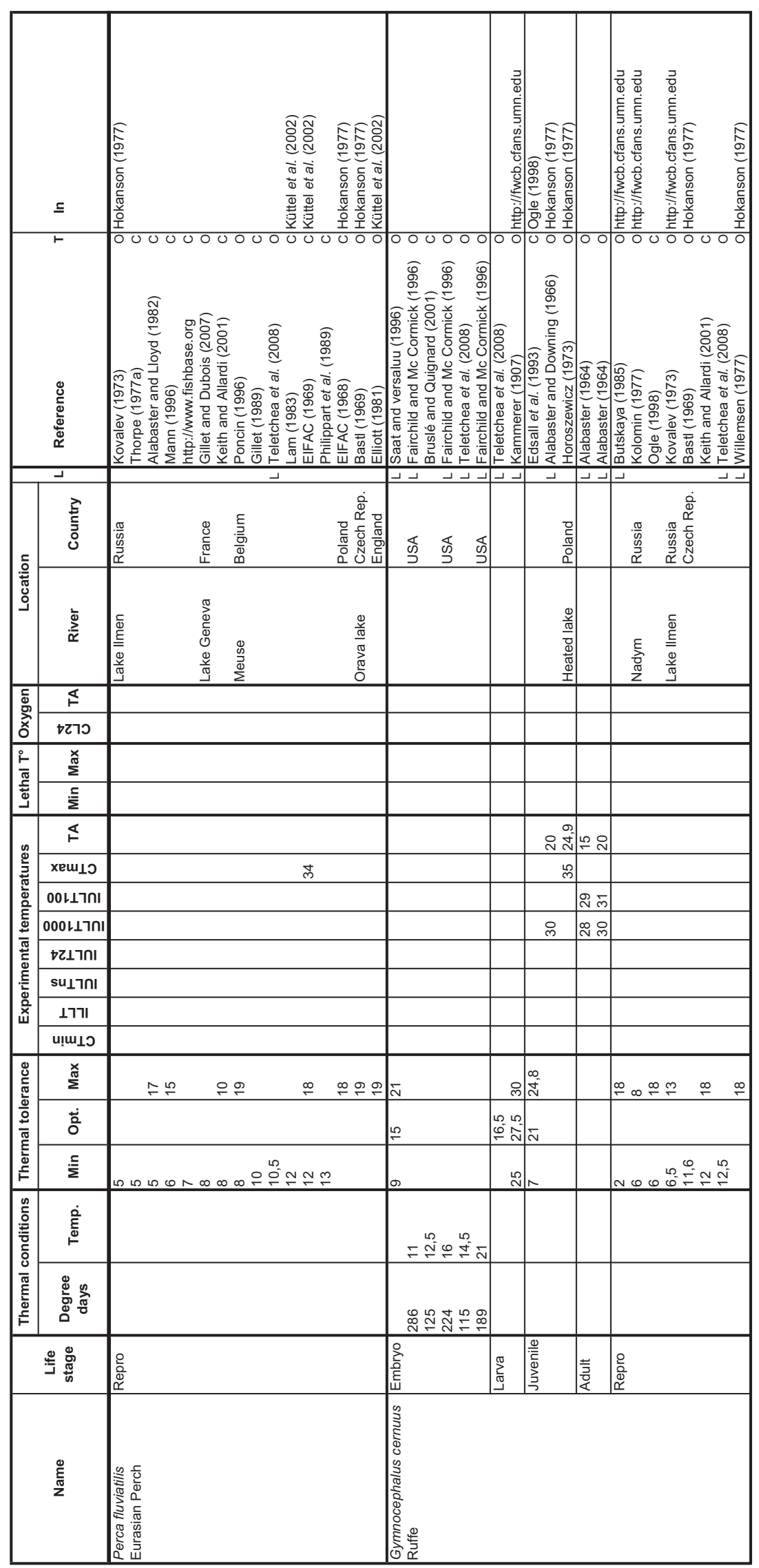




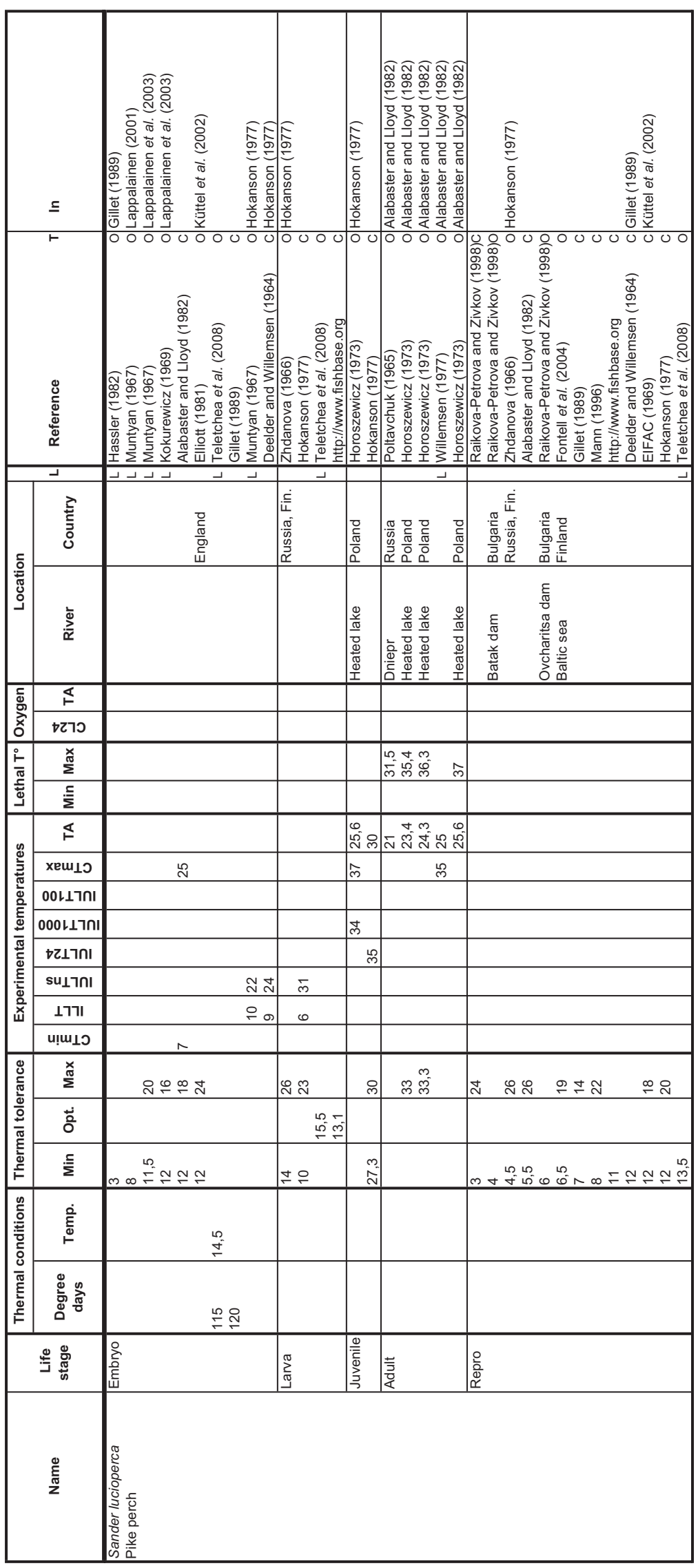




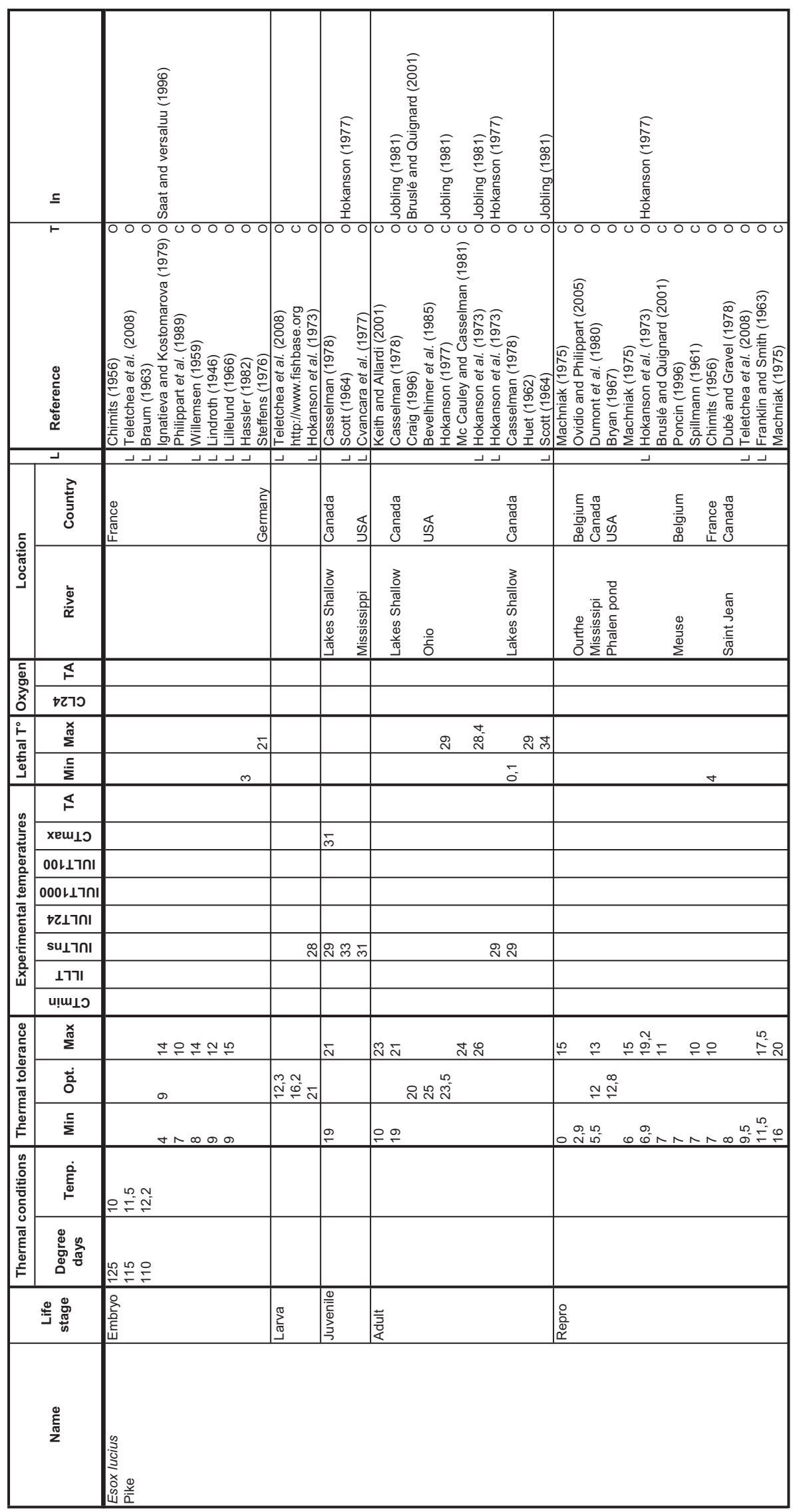




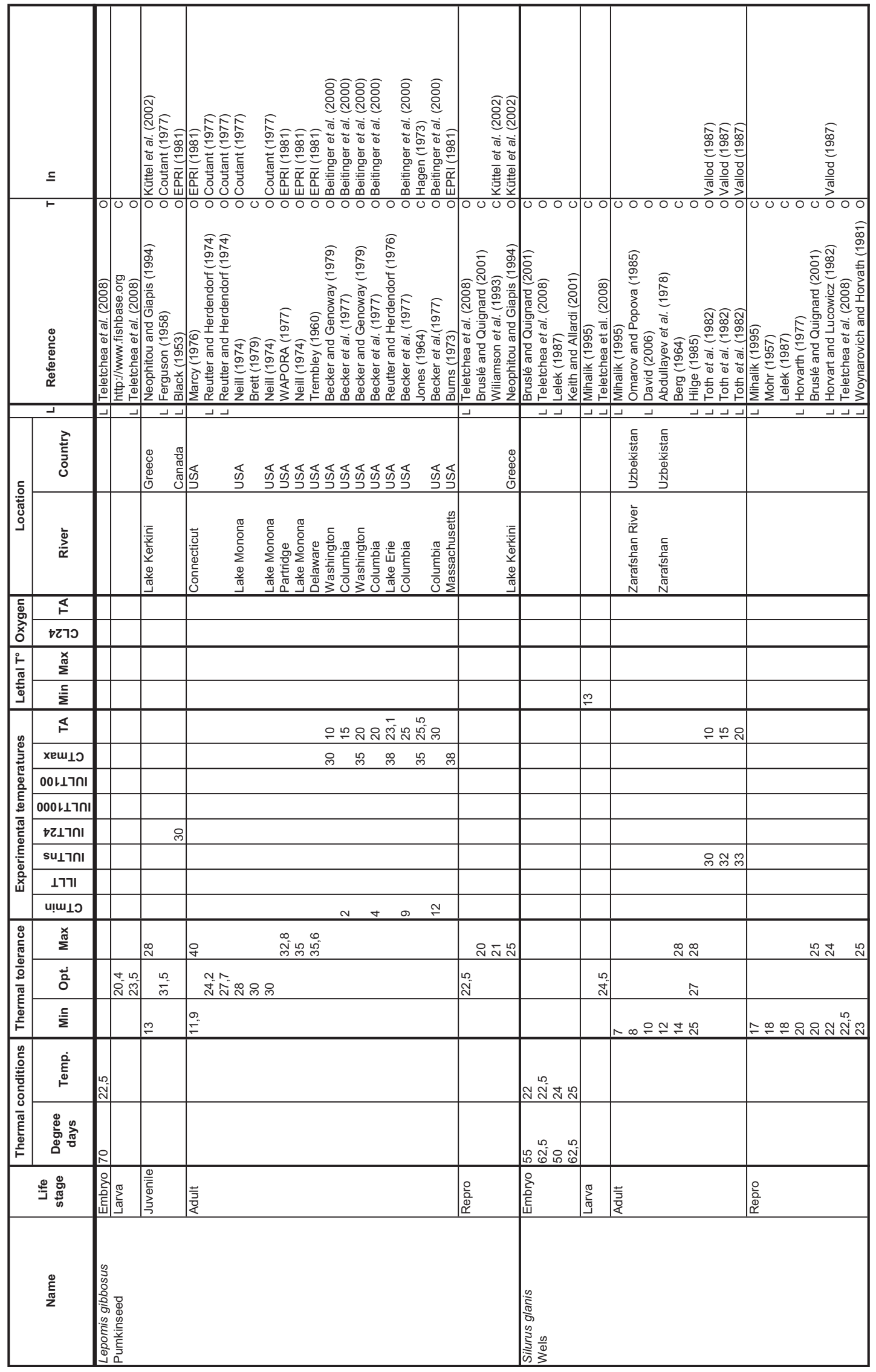

